2017-04-11

From Oppel to Callomon (and beyond):

building a high-resolution

ammonite-based biochronology for the

Jurassic System

Page, KN

http://hdl.handle.net/10026.1/9230

10.1111/let.12209

Lethaia

All content in PEARL is protected by copyright law. Author manuscripts are made available in accordance with publisher policies. Please cite only the published version using the details provided on the item record or document. In the absence of an open licence (e.g. Creative Commons), permissions for further reuse of content should be sought from the publisher or author. 


\title{
From Oppel to Callomon (and beyond): Building a high resolution ammonite-based biochronology for the Jurassic System
}

\author{
Kevin N. Page
}

School of Geography, Earth and Environmental Sciences, University of Plymouth, Drakes Circus, Plymouth, PL4 8AA, UK (kpage@plymouth.ac.uk)

\begin{abstract}
By 1849 Alcide d'Orbigny had proposed a very modern looking global subdivision of a Jurassique 'System', into a sequence of 10 étages. D'Orbigny's stages were based on a basic biostratigraphical framework, but there were still a number of issues with its actual demonstrable applicability internationally. In 1856
\end{abstract} Albert Oppel, however, took d'Orbigny's framework and, as stated by W.J.Arkell in 1933, "breath[ed] new life into it...placing the whole science of stratigraphical geology on a new footing...' Oppel recognised eight 'Etagen', divided into a sequence of 'Zones' which he considered to be time-related to correlation units of theoretically universal application - a very clear and unambiguous statement of what now would be considered to be chronostratigraphic practice. Subsequently, evolution of Jurassic stratigraphy had, by the end of the $18^{\text {th }}$ Century led to S.S Buckman's high resolution ammonite correlation schemes using hemera - essentially the same as modern biohorizons. Although some of this detail was subsequently lost in his syntheses, from around 1933 to 1956 W.J. Arkell took many pre-existing 'zonal' schemes and began to develop global 'standard' ammonite correlation schemes -again explicitly chronostratigraphical. Nevertheless, the potential for very high resolution ammonitebased correlation schemes - with a resolution of only around 100,000 or less - was soon rediscovered and promoted by J.H. Callomon and by a very active 'French School'. Despite all this activity, however, we still have not quite realised the ordered stratigraphical dreams of Oppel and his successors. Of the 11 stages now formally recognised within the Jurassic, 4 still do not have a ratified GSSP, and within the entire system, there still appear to be no formal agreements on what really are the 'standard' zones for each stage. Crucially, however, confusion is still widespread as to the 'meaning' of these zones - Jurassic 'Standard Zones' are chronozones not biozones - they have been explicitly so since Oppel's day, and as the stratigraphical building blocks of all 'modern' Jurassic stages, they must still be.

Key words: Jurassic, ammonites, Oppel, stratigraphy, zones. 


\section{Introduction: The origins and evolution of the 'Jurassic' as a division of geological time}

\section{Birth of a system}

The geological pioneer Alexander von Humboldt (1769-1859) is credited with the first use of 'Jura' as early as 1799 , in connection with the thick carbonate successions typical of the Jura Mountains of the NE Switzerland-French border territory which he initially termed the 'Jura Kalkstein'. By 1823, however, he was using the more specific terms 'Jurassique' and 'Jura Formation' (Woodward 1893), but still in a geographical and lithological sense, rather than chronological. Indeed, von Humbolt actually believed that these limestones were older than the Triassic Muschelkalk (Ogg and Hinnov 2012a).

By 1813, the English pioneer W.D. Conybeare had already compared (i.e. correlated) the limestones of the Jura Mountains with the Middle to Upper Jurassic 'Oolitic' formations of England, although basing his conclusions on earlier descriptions by Giovanni Arduinno from 1759 (teste Woodward 1893, p.1). When Alexander Brongniart (1770-1847), made the same comparison in 1829, however, he used the term 'Terrains Jurassiques', more explicitly linking back to Humbolt's original use of the term Jurassique. That such links could be made, however, is a consequence of the detailed stratigraphical and palaeontological studies of a number of earlier studies, most notably including the English pioneer of stratigraphical practice, the canal engineer William Smith (1769-1839), who, by 1799, already had a working fossil-based correlation scheme for the named, lithological units that he had mapped around the city of Bath in SW England (and which would later be recognised as being of Jurassic age). This mapping - and his more famous 1815 map of England and Wales - was supported by his milestone biostratigraphical atlas and guide of 1816, 'Strata identified by Organised Fossils' (www.strata-smith.com). As stated by John Phillips in 1829 (p. vii), Smith's "affectionate nephew and grateful pupil' (and later professor of geology at the University of Oxford):

"The first person in England who studied, and who taught others to study, the structure of the Earth... Having provided himself with the methods of identifying the 
strata by the attentive examination of all the circumstances which distinguish the one from the other, and especially by a comparative survey of their organic contents, he extended his observations to districts far distant from that in which they were originally commenced, and fixed at length, on a substantial basis, the important doctrine of general formations."

Smith's scheme of lithologically and palaeontologically defined 'formations', however, is not readily applicable outside of England, and even in Great Britain, his methods were not initially widely accepted. Strongly influential in this lack of progress was the state Geological Survey whose: “... authors [had] rejected the principle of identification [of rock units] by the organized fossils, a principle which I consider as the most important yet established in geological science.." (Phillips, 1829, xi-xii)

Curiously, however, even as late as 1871, Phillips himself continued to use divisions of 'Liassic', 'Bath Oolite', 'Oxford Oolite' and 'Portland Oolite' periods to group rock units which elsewhere had already been referred to a Jurassic System for many years (cf. Woodward 1893, p.1).

Although the Smith's original English scheme of subdividing what was to later become known as the 'Jurassic', the relatively simple southern German tripartite lithological subdivision of Leopold von Buch (1774-1853) from 1839 into 'Black' (i.e. mudrock-dominated), 'Brown'(sandstones and ferruginous limestones) and 'White' (pure limestone) Jura (later 'Lias', 'Dogger' and 'Malm' ) has survived, as these broad units (equivalent perhaps to modern lithostratigraphical 'groups' or 'supergroups') broadly correspond to 'Lower', 'Middle', 'Upper' Jurassic as already in use by the late $19^{\text {th }}$ century in the UK (Woodward 1893) and still in use today.

\section{Alcide d'Orbigny and the origin of Jurassic Stages}

Alcide D'Orbigny (1802-1857) was based at the Museum National d'Histoire Naturelle in Paris, and extensively toured South America, eventually becoming professor of palaeontology in 1853. In 1840, the first volume of his methodical description of French fossils - La Paléontologie Française - was published, eventually running to eight volumes (Rioult 1971). 
From 1842 to 1851 , d'Orbigny proposed a very modern looking global subdivision of a 'Jurassique' System into a sequence of 10 'étages' (Figure 1), inspired by many pioneering works from across Europe and further afield. To a certain extent his attempt to develop subdivisions was born of a sense of despair:

"How are groupings based only on lithological characters to be dealt with when they have been seen to be misleading? ..how can one rely on the nomenclature of the fossils recorded.. when one sees these fossils identified by authors with such irresponsibility that it is often necessary to ignore half of the identifications?"

"Confronted with these insurmountable difficulties I have found only one solution possible, and that was to consult nature herself." (1842-1849, pp.600-603; translated by W.J. Arkell 1933).

To such ends, D'Orbigny travelled extensively around France examining local sections - but his correlations of sequences elsewhere were based primarily on published records by those people he obviously considered were not quite so "irresponsible" in their fossil identification.

Although D'Orbigny's stages were based on a biostratigraphical framework composed of a sequence of 'zones', the faunal changes between the stages he recognised were envisaged as being more due to global catastrophes and replacement rather than continuous evolution (no doubt influenced by Georges Cuvier's - Professor of Comparative Anatomy at the Museum of Natural History in Paris from 1802 (Gayrard-Valy 1994) - persuasive presentation of his catastrophist view of the progression of life on Earth ):

"Geologists in their classifications allow themselves to be influenced by the lithology of the beds, while I [utilise] for my starting point... the annilation of an assemblage of life-forms and its replacement by another. I proceed solely according to the identity in the compositions of the faunas, or the extinction of genera or families ...the expression of the division which nature has delineated with bold strokes across the whole Earth." (loc. cit.: trans. W.J. Arkell 1933).

We can discuss this philosophy now in the light of modern attempts to find mass extinctions and other global events at every tick-tock of the geological clock (cf. Raup and Sepkoski's, 1984 'periodicity' of mass extinctions..), but as W.J. Arkell 
observed in 1933, in his unsurpassed review of the development of Jurassic stratigraphy: "These are the words of an enthusiast carried away by his subject and un-fettered by too much knowledge."

Nevertheless, d'Orbigny's contribution to the development of the geological time scale cannot be overemphasised, even though some of the detail of his schemes was flawed and not all of his claims of correlations could be substantiated - as already pointed out by Friedrich August von Quenstedt in 1858.

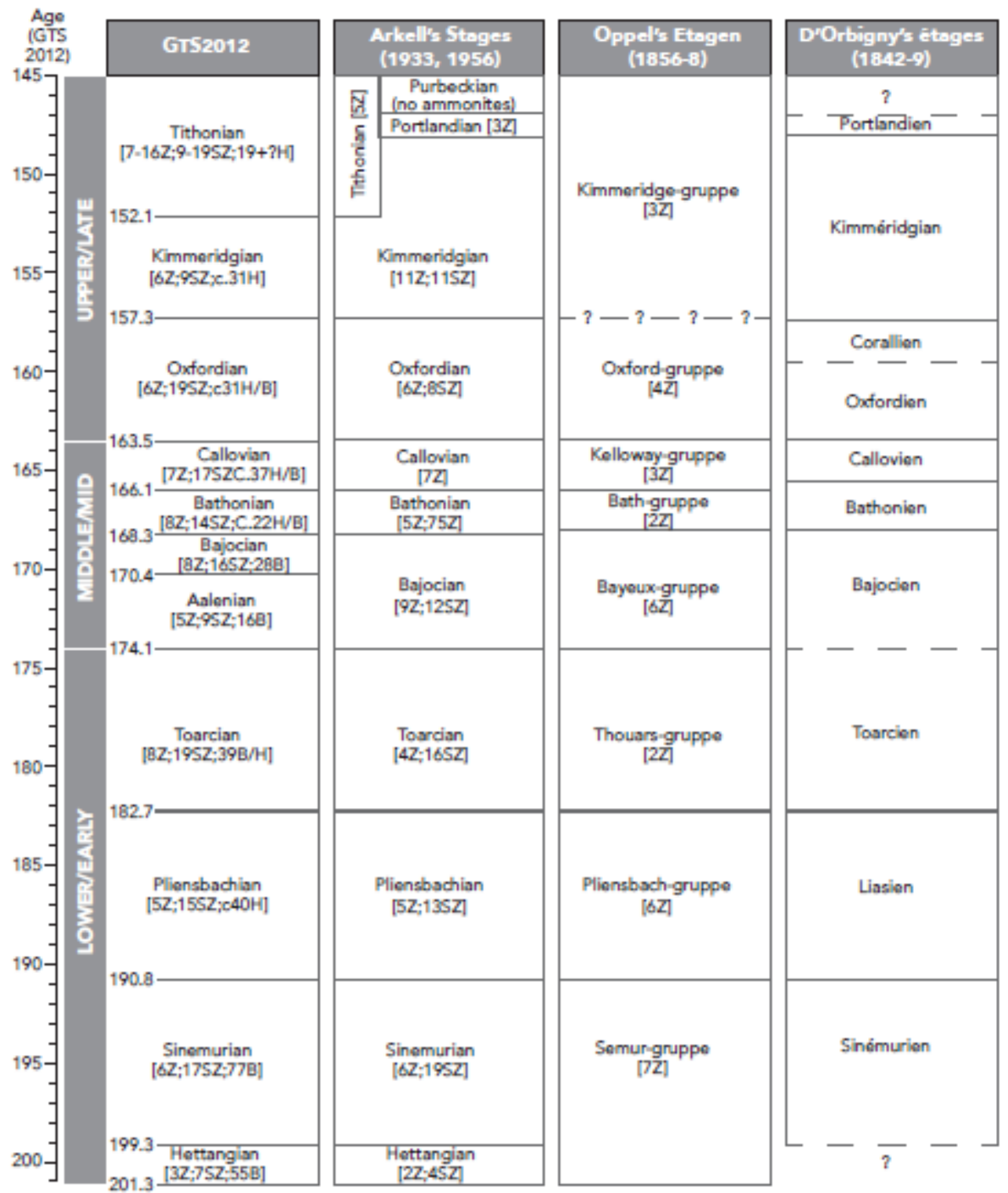

Figure 1 - The evolution of Jurassic Chronostratigraphical subdivisions from d'Orbigny to Oppel to Arkell correlated against the standard geochronological calibration of Jurassic Stages by Ogg and Hinnov (2012a) in GTS2012. The available resolution at a substage level is indicated by Z ( = Zone/ Chronozone), S (= Subzone/ Subchronozone), H (= Horizon), B (= Biohorizon) (but noting that d'Orbigny's 'zones' are not sufficiently well defined to be included). 


\section{Friedrich August von Quenstedt - attention turns to detail}

Friedrich August von Quenstedt (1809-1889) was professor from 1837 at the Eberhard Karls Universität in Tübingen, Germany. In his classic and detailed study of Jurassic sequences in Wüttenberg, Der Jura, published in 1858, he had no pretentions to use his findings to model the world, as D'Orbigny had, stating:

"...the...task which we have to fulfil in connection with the Jurassic is to draw up sections as faithfully as possible in the different districts... The accurate comparison of two successive beds three inches thick by means of their actual contents can contribute more fruitfully to the development of the science than the cataloguing of stages from the farthest corners of the Earth, when it has to be admitted, as a matter of course, that they are not correct." (1858, p.23; trans. W.J. Arkell 1933).

His eight pages of criticism of d'Orbigny were withering, but certainly coloured by the way d'Orbigny had often ignored the priority of the work of others, including Quenstedt's own...:

“...of what avail is it if a man has seen the whole world, and he does not understand aright the things which lie in front of his own doors?"

"Let us not weary of our searching our strata; let each of us collect as much as he can in his own neighbourhood, labelling the specimens exactly with their localities; then at least the first goal of all geological research should not remain far from our reach - a true table of the succession of the strata" (1858, p.823; trans. W.J. Arkell 1933).,

Quenstedt's other great contribution to Jurassic stratigraphy is his large format Die Ammoniten des Schwabischen Jura (1883-1888), truly the most beautifully and artistically arranged ammonite monograph ever produced.

\section{Carl Albert Oppel and the birth of a rigorous stratigraphical geology}

Quenstedt's plea for careful and systematic observation, and an evidence base for broader conclusions, clearly inspired one of his pupils, Albert Oppel (1831-1865). Oppel was born at Hohenheim in Württemberg, and went on to study at the 
University of Tübingen, where he graduated with a Ph.D. in 1853. As WJ Arkell put it, Oppel was:

"Young gifted [and] with more than ordinary powers of observation, generalisation and exposition". He was "The man... who was to place the whole science of stratigraphical geology on a new footing and to breathe new life into it' (1933, p.15).

Oppel studied first the Jurassic rocks of his southern German, Swabian home and then, in 1854, he set out to travel across Europe - to Switzerland, France and England - to try and establish a reliable correlation between each region using fossils chosen for their wide horizontal (i.e. geographical) but small vertical (i.e. chronological), range. His results were published in his seminal Die Juraformation Englands, Frankreichs and des südwestlichen Deutschlands (1856-1858; Figure 1 here),

He stated the problem as follows:

"Comparison has often been made between whole groups of beds, but it has not been shown that each horizon identifiable in any place by a number of peculiar and constant species is to be recognized with the same degree of certainty in distant regions"... "The task is admittedly a hard one, but it is only by carrying it out that an accurate correlation of a whole system can be assured."... "It necessarily involves exploring the vertical range of each separate species in the most diverse localities, while ignoring the lithological development of the beds; by this means will be brought into prominence those zones which, through the constant and exclusive occurrence of separate species, make themselves of from their neighbours as distinct horizons. In this way is obtained an ideal profile of which the component parts of the same age in the various districts are characterised always by the same species." (1856-1858, p.3; trans. WJ Arkell 1933).

According to Arkell: "This passage represents one of the most important landmarks in the progress of stratigraphical geology, for it contains the first germ of the conception of a detailed time-scale, abstracted from local considerations, either lithological or palaeontological."

Within each of his eight 'Etagen' (or 'Zonengruppen'), Oppel established a sequence of 'Zones' each to be identified by a characteristic fossil indicator species. Although 
he was not the first to use this term in the context of characterising, even correlating parts of a stratigraphical sequence, he greatly refined its use: "emanciating...zones from the thralls both of local facies, lithological and palaeontological, and of cataclysmic annilations, thus giving them an enormous extension and transferring them from mere local records of succession to correlation-planes of much wider and (theoretically) universal application". (Arkell 1933, p.17 - a very clear and unambiguous statement of what today we would call chronostratigraphy (see also Balini et al., this volume),).

Of all the available indicator species for his fossil zones, Oppel clearly recognised that ammonites were the most useful and of his 33 zones, 22 were based on ammonites (and all of remainder were subsequently assigned ammonite indices by later authors). Oppel was not, of course, the first to recognise the great potential of ammonites for correlation, William Smith used some ammonites species to establish his correlations (1816-1819) and they were a notable part of d'Orbigny's scheme, but it can be argued that Oppel finally established the group as the Jurassic stratigraphical tool, par excellence.

Subsequently, however, Oppel's relatively simple scheme was added to by a myriad of local studies, not least to help make sense of regional, biogeographicallyinfluenced variations. Nevertheless, as noted by Arkell (1933 p. 17): “...complete independence of action is allowed to the individual author, and he is at liberty to cumber terminology with as many new zones as may seem to him desirable, no matter how local his requirements, his knowledge, his outlook" (and it was this proliferation of terminologies that Arkell sought to rationalise in his two most remarkable works on Jurassic stratigraphy, firstly on the United Kingdom in 1933) and subsequently the World in 1956)

After Tübingen, Oppel went on to Munich in 1858, firstly as an assistant in the Palaeontological Museum, but from 1860 as the Professor of Palaeontology in the University. He died in December 1865 at the tragically young age of 34 . 


\section{S.S. Buckman and high resolution ammonite stratigraphy}

If Oppel established the principles of a modern approach to chronostratigraphical practice, it was S.S. Buckman (1860-1930) who really began to realise the full potential of fossils to take such chronologies to their ultimate, high-resolution expression.

Sydney Savory Buckman was the son of Professor James Buckman, a well-known botanist and geologist of the time, and a teacher at the Royal Agricultural College in Cirencester. Although largely self-employed, S.S. Buckman followed his father's geological interests and by 1881 had already published a paper on the brachiopods and ammonites of the Aalenian-Bajocian, subsequently commencing a comprehensive monograph of the ammonites in 1887. Buckman was particularly fascinated by these ammonites and soon realised that the great variety of forms that he observed in the local quarries of North Dorset and South Somerset were, at least in part, related to a stratigraphical succession of closely related species that he could actually describe (just like Quenstedt and Oppel before, he made himself master of his own district before applying himself further afield).

He soon realised that he could recognise very fine stratigraphical divisions based on this sequence of ammonite faunas, for which he coined the term 'hemera', explicitly calling them "chronological divisions" in 1893, recognising that this time scale was entirely independent of the deposits actually preserved. Buckman defined hemera as: "..its meaning is 'day' or 'time'; and I wish to use it as a chronological indicator of the faunal sequence." (1893):

"Successive 'hemerae' should mark the smallest consecutive divisions which the sequence of different species enables us to separate in the maximum development of a strata.... It is designed as a chronological division and will not replace the term zone or be a subdivision of it, for that term is strictly a stratigraphical [i.e. rock] one...It must be particularly understood that it is used in a chronological sense as a subdivision of an 'age" (1902).

Buckman grouped his hemera into 'ages', but as the council of the Geological Society of London - a major power in UK geology at the time - were not happy with this use of stratigraphical terms in a chronological sense as (they believed it would 
lead to confusion), Buckman became the first to introduce a dual rock-time / geological time terminology in 1898, as we still use today.

Nevertheless, he remained widely misunderstood - not least as he largely operated outside of the geological establishment at the time - and the difference between the preserved rock succession and the actual passage of time was still not grasped by many. In an attempt to try and explain his ideas, he published an explanation in 1902 , using the story of a Dorset quarryman's lunch.

"Sir, your dawg a bin an yet my fittle" must be one of the best discussions of the relationship between geological time and the rock-record ever published. In this scenario, the quarry owner's dog had eaten the quarry worker's lunch, hence there was nothing remaining to represent his 13:00 'lunchtime' and there was, therefore, a gap in the sequence of his lunches. Nevertheless, lunch or no lunch, 13:00 had still arrived and passed, even though the (edible) 'deposit' representing lunch no longer existed (it had been removed by the 'erosive' force of dog). Based on this analogy, Buckman argued that it was essential, therefore, to distinguish between a deposit of 'lunchtime' (i.e. 'rock-time' or chronostratigraphy) and the actual passage of real time (i.e. with respect to a geochronological time scale). As he later concluded in 1922 (: "Geological strata are made as the net result of a constant battle of addition versus subtraction, in which are seen, locally, the small, slow victories of addition, after many vicissitudes."

Buckman introduced many other terms such as biozone and faunizone, although both would have a meaning closer to a modern usage of biozone, and most have not stood the test of time (see discussion by Arkell 1933, pp.17-25). His high-resolution ammonite based chronology, however, is still very relevant, even if, ultimately, his sequencing of faunas became increasingly hypothetical (as in his Type Ammonites series published from 1909 to 1930).

Crucially he grouped his hemera into 'ages' which were explicitly the time period over which a 'stage' was deposited, and these were further grouped into 'epochs', another time-related term still very much in use today. He also seems to have been in little doubt that each hemera could be of different actual chronological duration but were certainly very short geologically, possible ranging from 100 s to 1000 s of years. 


\section{W.J. Arkell and the Jurassic World}

Inevitably, however, considerable confusion remained over use of the term 'zone' in Jurassic stratigraphy, despite the efforts of Oppel, Buckman and others to clarify, even crystallise an explicit meaning. Buckman's ideas, in particular, were poorly understood by most of his contemporaries and it was not until 1933, that W.J. Arkell brilliantly synthesised the development of Jurassic stratigraphy, truly setting the record right concerning all that had developed beforehand, from von Humbolt to S.S. Buckman, and providing a clearly stated stratigraphical meaning for the myriad of pre-existing terms, both conceptual (e.g. in the sense of zonal terminology) and chronological (e.g. the many new stage names created by various authors for parts of the Jurassic post-Oppel).

W.J. Arkell (1904-1958) was born into a well-known beer-brewing family in Wiltshire, and just like the others before him, set out to describe the rich Upper Jurassic sequences around both his family home at Highworth in Wiltshire and their holiday home at Ringstead on the Dorset coast (e.g. 1936, 1935-1948, 1941, etc - see listings in Arkell 1956, pp. 644-645). He was awarded a lectureship in geology at New College in Oxford in 1927 and was made a Senior Research Fellow of the same College in 1929. However, as his College duties were limited, he was able to devote a lot of his time to research - one of the few examples of where brewing has subsidised geological activity, rather than the other way round.

His first real landmark in Jurassic Stratigraphy was the publication in 1933, at the age of only 29, of The Jurassic System of Great Britain, in which he reviewed and synthesised virtually everything that had happened in the UK since the pioneering days of William Smith, at the end of the 18th century. This work firmly established Arkell as an authority on the Jurassic, not least because in the introductions to the book, he reviewed the development of Jurassic stratigraphical terminology including at zonal and at stage level - thus providing probably the first real attempt at a consolidation and standardisation since Oppel's time.

His other milestone contribution, was his Jurassic Geology of the World, published in 1956, in which he applied the principles established in 1933 - along with his 
tremendous knowledge and experience - to provide a rigorous stratigraphical framework within which to compare Jurassic sequences across the entire planet (Figure 1). In this context, Arkell firmly established Jurassic stages as globally applicable units, consolidating what Oppel had attempted to prove so long before. Nevertheless, as part of the process to find globally applicable standards, some of the very fine detail that Buckman had laboured so hard to demonstrate, was almost lost.

\section{The 'French school': horizons and 'zonules'..}

And so Jurassic stratigraphy largely remained in the UK, fixed on zonal schemes largely consolidated prior to 1960 in true Arkellian style. Meanwhile, however, across the Channel things continued to develop, as a new generation of ammonite biostratigraphers went back to their local rocks - as Quenstedt and Oppel had done before in Germany - and started to the describe the very real detail present in successions of Jurassic ammonite assemblages in France. The first wave of results was presented at the 1967, Colloque du Jurassique á Luxembourg - perhaps the first really significant international Symposium on the stratigraphy and palaeontology of the Jurassic System.

The conference proceedings were not published until 1974, but include some of the first descriptions of a high-resolution framework which is well-established today. After what is effectively a 'key-note' introduction by Gabilly (1974) on the methodology adopted, a suite of detailed summaries of the sequence of ammonite assemblages present in key regional sequences followed (including Gabilly , Elmi, Mattei, Mouterde and Rioult (1974) on the Toarcian; Mangold, Elmi and Gabilly (1974) on the Bathonian; Cariou, Elmi, Mangold, Thierry and Tintant (1974) on the Callovian; and Enay, Tintant and Cariou (1974) on the Oxfordian), each stage with a detailed sequence of sub-subzone correlative units termed 'horizons'.

This French concept of 'Horizons', however, has often been confused with other infra-subzonal units, in particular biohorizons - a modern term for the faunal 'events' that S.S. Buckman's called hemera (as discussed below). French 'horizons' are, however, effectively sub-subzones as they completely fill the stratigraphical column 
(see Figure 2), without gaps or overlaps, and hence should be defined in exactly the same way, with a basal boundary stratotype in true chronostratigraphical fashion (i.e. with their top being 'defined' by the base of the succeeding division of the same scale; see http://www.stratigraphy.org/index.php/ics-stratigraphicguide).

Phelps (1985), realising the distinction between French 'Horizons' and other highresolution units equivalent to biohorizons, adopted the term 'zonule' to distinguish them - this distinction was maintained by some subsequent authors such as Page (1995, 2003). As pointed out by J.H. Callomon (pers. comm. 2006), however, the term 'zonule' as originally proposed by Fenton and Fenton in 1928 in the sense of the vertical range of a defined fauna and its geographical extent, has more to do with biostratigraphy than chronostratigraphy.

Whatever, the philosophy behind the type of infra-subzonal unit adopted, however, what is crucial in the process is that fine scale chronology-related changes in fossil assemblages with correlative potential (at least regionally), can still be recognised, described and used without disrupting the nomenclatural stability (and hence wider utility) of schemes of higher stratigraphical units at the level of zone and subzone.

Although, developments and refinements have of course continued, the definitive expression of the development of these French horizonal schemes (now only excluding the Tithonian), is presented in the extremely useful Biostratigraphie de Jurassique ouest-européen et méditerranéen, edited by $\mathrm{E}$. Cariou and $\mathrm{P}$. Hantzpergue in 1997 (and crucially integrated with stratigraphical reviews for other key fossil groups present through the System).

\section{J.H. Callomon and a Standard Chronstratigraphy}

As the potential for high-resolution stratigraphy using ammonites was being realised in France, a parallel Anglo-German approach was developing inspired by J.H. Callomon (1928-2010). Born in Berlin, John Callomon's family moved to the UK in 1937, where he attended Oxford University, meeting W.J. Arkell. Although Callomon ultimately graduated in Chemistry - becoming a Professor of Inorganic Chemistry at University College London - he had a parallel career as one of the world's leading specialists on Jurassic ammonites (encouraged initially by Arkell himself). Crucially, 
being fluent in English, German and French - and with a working knowledge of several other languages - he had an almost unique access to classical geological literature, including d'Orbigny, Quenstedt, Oppel and many others. And as a disciple of W.J. Arkell, he was also a staunch proponent of a formal chronostratigraphy, and it is the very clear concept of time and stratigraphy that Callomon had which should live on and guide us into the future.

He had a characteristic disdain for international committees, continuously reminding congresses of the principles of a formal chronostratigraphy, his exasperation at times showing - not least in his 1984 presentation at the Erlangen International Symposium on Jurassic Stratigraphy, entitled: "Biostratigraphy, Chronostratigraphy and all that - again!". In his published text he stated: “...to help allay some of the confusion still regrettably to be found on such occasions, it seems worthwhile at a colloquium on Jurassic Stratigraphy to recapitulate some basic principles... To date rocks (other than radiometrically) requires the construction of standard chronostratigraphical scales of reference... The commonest, most versatile and most powerful tools in Phanerozoic correlation are fossils, because some biozones or their boundaries approximate closely to time-planes". (published 1985).

He discussed primary and secondary standards for stratigraphical units and identified three basic stages in the process of "practical" chronostratigaphy, e.g.:

1. Evaluation of stratigraphical indicators; 2 . Construction of standard chronostratigraphical scales; 3. Choosing a primary standard; concluding , "Which is what we have been doing since Oppel's time, even if we have not been aware of it'.

As part of this process, Callomon also re-instated Buckman's concepts of a high resolution ammonite based biochronology, undoubtedly strongly influenced by $R$. Brinkmann's famous and irrefutable 1929 demonstration of the successive finescale changes that can be observed in a systematically sampled sequence of ammonite faunas (reference to Brinkmann's work surfaces in many of his general ammonites and time papers, for instance Callomon 1963, 1995, etc). Callomon adopted the term 'faunal horizon' to describe his concept of high resolution biochronological units, which he considered to be the rock (i.e. a chronostratigraphical unit) equivalent of Buckman's original hemera (i.e. geochronological units) (1995). Nevertheless, in a practical context, Callomon's 


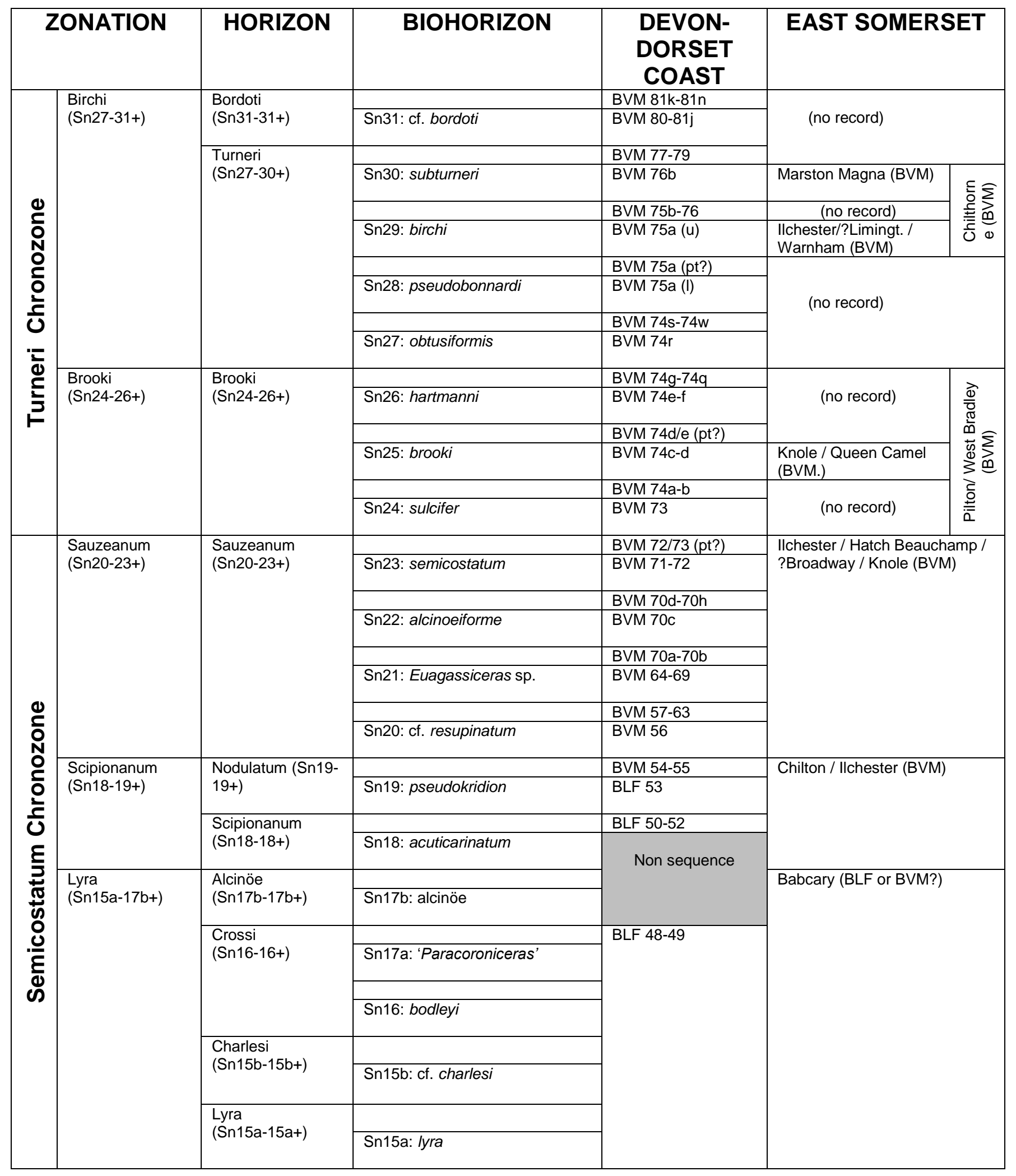

Figure 2 - Correlating with biohorizons; an example from the upper part of the Lower Sinemurian of south west England (modified from Page 2010a; BLF = Blue Lias Formation, BVM = Black Ven Marls Formation). Note that intervals between biohorizons are also correlated on the Devon-Dorset coast, and can be indicated by including a '+' symbol after the biohorizon immediately below, e.g. Sn 32 and Sn32+. Records from East Somerset, however, are based, on spot faunas from temporary excavations collected by H.C. Prudden near the named settlements, hence they may be grouped according to the stratigraphical range of the components of these faunas, where assignment to a single biohorizon is not possible. 
'faunal horizons' wre virtually the same as Buckman's hemera being the "smallest consecutive divisions which the sequence of different species enables us to separate in the maximum development of a strata", although freed of some of Buckman's baggage of species 'acmé' (i.e. his perception of the successive flourishing and dominance of a single species) and other misconceptions (1985a,b, 1995, pp.50-53).

Callomon explicitly referred to such faunal 'events' as being like "frames in a moving picture"- taking an analogy from Bather (1927) - literally 'snapshots' through time of evolving ammonite populations which could be valuable for correlation (1985b, 1995). Crucially, however, as in movie film there is a time 'gap' between each image, during which things have, in an evolutionary sense, moved on - and hence, any table of such horizons must show stratigraphical gaps between each successive unit (cf. Page 1995, p.803, Figure 2 here). To help distinguish between Callomonian 'faunal horizons' and French 'Horizons' (which are effectively sub-subzones), the term biohorizon is preferable as adopted by Page $(1992,1995)$ - although hemera would still be its time duration on a geochronological scale.

Publishing mainly on non-UK successions, Callomon's work included studies of the ammonites of East Greenland (e.g. Callomon 1993; Callomon and Birkelund 1980, 1982; Birkelund, Callomon and Fursich 1984) and from Southern Germany- the latter in collaboration with colleagues from the Staatliches Museum fur Naturkunde in Stuttgart (e.g. Dietl and Callomon 1988, Callomon, Dietl and Niederhöfer 1989, etc). This work also includes many stages in the development of a biohorizonal scheme for the Lower Callovian of the latter area, as published in correlation with a scheme then under development for the UK Lower Callovian (Callomon, Dietl and Page 1989). Probably the most complete biohorizonal scheme Callomon contributed to, however, was that for the Aalenian-Bajocian of southern England, based on the extremely detailed and systematic sampling by Robert Chandler of the same sequences that S.S. Buckman had first studied (Callomon and Chandler 1990).

Application of a similar methodology subsequently led to the establishment of further biohorizonal schemes in the UK and biogeographically related areas for the 
Hettangian, Sinemurian, Lower Toarcian, Bathonian, Lower Callovian and across the Callovian-Oxfordian boundary and part of the Middle Oxfordian (Page 1992, 2004, 2005, 2010a; Bloos and Page, 2000; Dommergues, Meister and Page 1994; Page and Meléndez 2000; Page, Meléndez and Wright 2010; Page, Wright and Kelly 2015 , etc). This is not to imply, however, that other advances have not been made in the UK, as J. C. W. Cope's detailed sampling of the classic Kimmeridge Clay sequences (Kimmeridgian - Tithonian) of Dorset (1967, 1978), SW England, laid the foundation for a new and detailed Boreal zonation - its just that the new correlative units were recognised at the level of 'subzone' and 'zone', rather than 'horizon'. Refinements at the level of 'biohorizon' have also continued in Germany, in particular for the Callovian by Mönnig (2010, 2014, this volume).

What has become very clear from this work is that an original 'standard zonal' (i.e. chronozonal) framework for these intervals could be refined at least 4 times, sometimes more, as between 2 and 7 biohorizons can be recognised within almost every pre-existing subchronozone. For instance for the Sinemurian, from an original 17 subzones (following Dean, Donovan and Howarth 1961), around 77 biohorizons can currently by recognised - an x4.5 increase in available stratigraphical resolution. And for the Hettangian, work in progress, indicates that around 55 biohorizons can recognised within standard 8 subchronozones and chronozones - a nearly sevenfold increase in available resolution.

Surprisingly, however, it has taken a long time for any of these available highresolution schemes - both French and UK - to permeate UK Jurassic-focussed stratigraphical literature, which has often continued to use Arkellian-style 'standard zonations', some dating from the early 1960s (e.g. in Howarth 1992; Jenkyns et al. 2002; Ruhl et al. 2010, etc). Elsewhere, however, high resolution correlative schemes using ammonites, including using biohorizons, are gradually being established and applied (e.g. Blau and Meister 2000, Wierzbowski and Matyja 2014, Pellenard et al. 2014, Kiselev et al. 2006, Hillebrandt and Kment 2015, etc). 


\section{The resolution of biohorizons..}

But when we talk about high resolution, however, what exactly does this mean in terms of geological time and correlative potential? Callomon (1985b) using the then available stratigraphical resolution for the Boreal ammonite family Cardioceratidae (terminal Bajocian to near the top of the Kimmeridgian), as well as latest 'calculated' duration for the Jurassic System and its component stages, estimated that each faunal horizon had an average duration of around 200,000 - 250,000 years (although his figure of 120,000 in Table 1 for an average duration for faunal horizons across the entire System, is an unsubstantiated 'guestimate)'.

Page (1995) also attempted to calculate a figure for the duration of Jurassic 'Horizons' sensu gallico and biohorizons in Europe using either existing or inferred biohorizonal and horizontal schemes (but note that for biohorizons, the 'duration' should be 'biohorizon-plus- interval', as the actual fauna containing beds could be of greatly different durations, as already realised by Buckman), However, unlike Callomon, the sources from which the 'inferred' horizontal schemes were derived were explicitly stated (in the legend to Text-Fig 2). Average durations were calculated in two ways, firstly using the calculated stage durations of the then available global time scale (e.g. Harland et al. 1990) and secondly, using the very few radiometrically dated geochronological tie-points, which the same authors had used to estimate the ages of stage boundaries. The figures obtained of between around 165,000 to 300,000 years, perhaps most reliably from the second method, were, however, not very dissimilar from Callomon's estimations.

Things have moved on, however, and the Jurassic timescale (for instance of Ogg et al. 2012a) has continued to be refined, including through both new radiometric dating and calibration against recorded Milankovitch cyclicity (see Weedon et al 1999). In the case of the Hettangian, where current estimates of duration vary between around 2.0 million years (based on radiometric dating of interbedded volcanics and assumed North America-Europe ammonite-correlations; Schaltegger et al. 2008) and 1.8 million years (derived from a study of Milankovitch cyclicity in the limestone-mudrock alternations of the Blue Lias Formation on the West Somerset coast, SW England and an assumption of continuous sedimentation; Ruhl et al. 2010), a new sequence of 55 biohorizons for the Stage (in the process of description), suggests an average 
biohorizon-interval duration of only a little over 36,000 years at this level (if Ogg and Hinnov's arbitrary addition of 0.2 My to compensate for Ruhl et al. incorrectly identified base of the Jurassic System is accepted). Weedon, Jenkyns and Page (2017), however, demonstrate that sedimentation rates were not uniform throughout the West Somerset sequence, hence implying that the Hettangian might actually be slightly longer. Nevertheless, preliminary figures calculated for an average biohorizon-plus- interval duration still indicate minimum durations of around 60,000 years or less.

This must surely be the "ultimate in a resolvable chronology" to quote Callomon (1985) and it is intriguing to speculate just how refined a time scale for the Jurassic might become once the use of ammonite-correlated horizons and biohorizons become more widely used - and is more accurately calibrated against established geochronological dating and Milankovitch cyclicity. But ammonites are almost certainly not unique in this respect, as already hinted at by Callomon (1995). In particular, as long ago as 1993, Loydell was able to estimate that most of the graptolite 'biozones' in the Telychian Stage of the Lower Silurian could be of "only a few hundred thousand years' duration". Similarly, using the dates for the Turonian Stage of the Upper Cretaceous provided by Ogg and Hinnov (2012b), in the Western Interior of North America, ammonite 'zones' apparent provide a correalltive resolution averaging around 300,000 years. Indeed, methodological changes to the way in which these and some other fossil groups (e.g. conodonts, foraminifera, preJurassic ammonoids, etc) are biostratigraphical categorised could undoubtedly achieve similar or even more refined results throughout the Phanerozoic, for example through the recognition of correlative units equivalent to biohorizons.

But what factors might underpin the recognition of such fine time divisions as biohorizons and horizons? Some review of 'definitions' might be useful at this point:

Standard Zones and Chronozones:

As ammonite-correlated 'Standard Zones' (sensu Arkell) in the Jurassic are conceptually Chronozones - and have been ever since they were first 'formalised' by Oppel - they should be formally defined at their base within a (lithostratigraphical) 
reference section (their top being correlated from the defined base of the next successive chronozone, which is very likely to have been defined at a different location). Exactly the same principle also applies to subchronozones and to all higher divisions in a standard chronostratigraphical hierarchy, from Stage to Subsystem to System, etc (see: http://www.stratigraphy.org/index.php/icsstratigraphicguide.).

Unfortunately, however, this meaning for Jurassic ammonite zones has confused many for a very long time (as observed by Ogg and Hinnov 2012a, p.748-7490, and despite efforts by Buckman (1893, etc), Arkell (1933, etc), Callomon (e.g. 1965, 1985a, 1995, etc, etc) and others, they are still commonly referred to as 'biozones' (e.g. in Whittaker et al. 1991). This interpretation is categorically wrong for the following reasons:

1. Ammonite 'standard zones' are correctly defined only at their base in a stratotype section. Crucially, most ammonite zones and subzones in the Jurassic now have such reference sections, although they were not necessarily always explicitly stated in their original descriptions (see Cox 1990).

2. The base of every proposed and/or ratified Jurassic stage-level GSSP corresponds, or will correspond, to the base of an ammonite 'standard zone' (e.g. see Ogg and Hinnov 2012a).

3. Ammonite 'standard zones' completely fill every Jurassic chronostratigraphical stage and hence the entire Jurassic chronostratigraphical time scale without gaps or overlaps (e.g. see stratigraphical columns in Ogg and Hinnov 2012a).

4. Ammonite 'standard zones' are composite units and are not defined or correlated solely on the presence or range of any index or other ammonite species or assemblage. They do not, therefore, correspond to the basic properties of conventional biozones (e.g. as classified by Whittaker et al. 1991, e.g. 'Total Range Biozone', 'Concurrent Range Biozone', 'Assemblage Biozone', etc). 
5. Ammonite 'standard zones' can be correlated by a wide range of other stratigraphical tools and methods, including brachiopods, microfossils (i.e. biostratigraphy), stable isotopes (i.e. chemostratigraphy) and magnetostratigraphy. This principle is firmly established and demonstrable within the establishment of every Jurassic stage-level GSSP, where proxies other than ammonites can be used to correlate the base of the lowest standard ammonite zone within the stage. Notable amongst these correlations is the use of carbon isotope stratigraphy to correlate the base of the Tilmanni Chronozone at the base of the Jurassic System, across Europe from the Austrian GSSP, as the index species (Psiloceras spelae Guex) is unknown elsewhere in Europe (see Clémance et al. 2010, Page 2010b, Weedon et al. 2017).

6. As with the base of a stage established through a ratified GSSP, a 'standard zone', or chronozone correlated primarily with ammonites, can be considered to mark an isochronous surface, or time plane. This is possible using fossils such as ammonites, as the rapidity of the geographical spread of the correlating nektonic-planktonic fauna is potentially much more rapid than the processes that facilitate the use of most other correlative tools (see Figure 4), even direct isotopic dating. This migration or other distribution event will, therefore, for all practical intents and purposes, appear to be 'instantaneous' within a geological timescale and $\underline{\text { no }}$ diachroneity will be apparent. For example, larval distribution via oceanic currents with a surface speed of up to $0.5 \mathrm{~m} / \mathrm{s}$ equatorially (http://oceanmotion.org/html/resources/oscar.htm) could conceivably allow a circum-global distribution equatorially in just over 30 months (2.56 years), assuming that no continental barriers existed. This figure is entirely consistent with observed larval distribution rates of modern marine faunas, for instance as quoted by Winkelman et al. (2013, e.g. Brazil to mid Atlantic in 50 days) and was used by these authors to help explain how the giant squid Architeuthis dux (Streenstrup) could have a global distribution with a low genetic diversity (e.g. larval drifting and adult migration allows all populations globally to mix genetically). 


\begin{tabular}{|c|c|c|c|c|c|}
\hline $\begin{array}{l}\text { CORRELATIVE } \\
\text { TECHNIQUE }\end{array}$ & $\begin{array}{l}\text { RESOLUTION } \\
\text { (e.g. when } \\
\text { correlating } \\
\text { boundaries/ } \\
\text { changes) }\end{array}$ & $\begin{array}{l}\text { AVERAGE } \\
\text { DURATION OF } \\
\text { UNITS }\end{array}$ & $\begin{array}{l}\text { INDEPENDENCE } \\
\text { FROM OTHER } \\
\text { TECHNIQUES }\end{array}$ & $\begin{array}{l}\text { DISTANCE FOR } \\
\text { CORRELATIONS }\end{array}$ & $\begin{array}{c}\text { NUMBER OF } \\
\text { POTENTIALLY } \\
\text { CORRELATABLE } \\
\text { UNITS } \\
\text { (duration of Jurassic } \\
=56.3 \mathrm{My} \text { ) }\end{array}$ \\
\hline $\begin{array}{l}\text { Biostratigraphy: } \\
\text { Ammonoidea }\end{array}$ & $\begin{array}{l}\text { Larval distribution via } \\
\text { oceanic currents with } \\
\text { a surface speed of up } \\
\text { to } 0.5 \mathrm{~m} / \mathrm{s} \text { (see } \\
\text { http://oceanmotion.org } \\
\text { /html/resources/oscar. } \\
\text { htm) could allow a } \\
\text { circumglobal } \\
\text { distribution in just over } \\
30 \text { months ( } 2.56 \\
\text { years). }\end{array}$ & $\begin{array}{l}\text { Potentially less than } \\
40,000 \text { yrs } \\
\text { (Hettangian); or } \\
110,000 \text { for } \\
\text { Sinemurian, } 130,000 \\
\text { for Aalenian- } \\
\text { Bajocian, etc (this } \\
\text { work) }\end{array}$ & $\begin{array}{l}\text { Yes (independent } \\
\text { biochronological } \\
\text { time scale } \\
\text { established) }\end{array}$ & $\begin{array}{l}\text { Can be circum- } \\
\text { global, with varying } \\
\text { degress of } \\
\text { bioprovincial control } \\
\text { in marine } \\
\text { environments }\end{array}$ & $\begin{array}{l}80 \text { Chronozones / } 161 \\
\text { Subchronozones / } 395 \\
\text { Horizons/Biohorizons } \\
\text { (could potentially be } \\
\text { increased to over } 500 \\
\text { at current resolution } \\
\text { for the Sinemurian or } \\
\text { over } 1500 \text { at current } \\
\text { Hettangian resolution) } \\
\text { (this work) }\end{array}$ \\
\hline $\begin{array}{l}\text { Chemostratigraphy } \\
\text { (Sr isotopes) }\end{array}$ & $\begin{array}{l}\text { c.50 ka maximum } \\
\text { resolution at } 2016 \\
\text { analytical capacity } \\
\text { (McArthur et al. } 2015 \text {, } \\
2016 \text { ) }\end{array}$ & Continuous change & $\begin{array}{l}\text { No - May require } \\
\text { calibration against } \\
\text { biochronological and } \\
\text { radiometric time } \\
\text { scales. }\end{array}$ & Global (marine only) & $\begin{array}{l}\text { Continuous change } \\
\text { (resolution suggests at } \\
\text { least } 1156 \text { resolvable } \\
\text { correlations might } \\
\text { possible) }\end{array}$ \\
\hline $\begin{array}{l}\text { Chemostratigraphy } \\
\text { (C isotopes) }\end{array}$ & $\begin{array}{l}2,000 \text { years for } \\
\text { oceanic mixing (in } \\
\text { current oceanic } \\
\text { configuration); } \delta C 13 \\
\text { peaks have a duration } \\
\text { (e.g. c. } 120,000 \text { yrs for } \\
\text { the Toarcian event, } \\
\text { according to Kemp et } \\
\text { al. 2011). }\end{array}$ & Probably variable & $\begin{array}{l}\text { No - requires } \\
\text { calibration against } \\
\text { biochronological and } \\
\text { radiometric time } \\
\text { scales. }\end{array}$ & $\begin{array}{l}\text { Global (marine and } \\
\text { non-marine) }\end{array}$ & $\begin{array}{l}\text { At least } 15 \text { potentially } \\
\text { correlatable } \\
\text { excursions (both -ve } \\
\text { and +ve) extrapolated } \\
\text { from Jenkyns et al. } \\
(2002)\end{array}$ \\
\hline Magnetostratigraphy & $\begin{array}{l}10,000 \text { years for } \\
\text { complete reversal }\end{array}$ & Variable & $\begin{array}{l}\text { No - requires } \\
\text { calibration against } \\
\text { biochronological and } \\
\text { radiometric time } \\
\text { scales. }\end{array}$ & Global & $\begin{array}{l}52 \text { polarity chrons } \\
\text { (Ogg and Hinnox } \\
2012 a)\end{array}$ \\
\hline $\begin{array}{l}\text { Geochronology } \\
\text { (radiometric dating) }\end{array}$ & $\begin{array}{l}\text { Typical dating errors } \\
\text { quoted in Ogg and } \\
\text { Hinnox (2012a) vary } \\
\text { from around }+/-0.2 \\
\text { upwards (e.g. from c. } \\
400,000 \text { yrs). See also } \\
\text { discussion of Schmitz } \\
\text { (2012). }\end{array}$ & Continuous change & Yes & $\begin{array}{l}\text { Global (marine and } \\
\text { non-marine) also } \\
\text { extra-terrestrial }\end{array}$ & $\begin{array}{l}\text { Continuous change } \\
\text { current (resolution } \\
\text { suggests at least } 140 \\
\text { distinguishable } \\
\text { intervals possible) }\end{array}$ \\
\hline $\begin{array}{l}\text { Cyclostratigraphy } \\
\text { (Milankovitch) }\end{array}$ & $\begin{array}{l}\text { c. } 20,000 \text { yrs cycles } \\
\text { potentially resolvable. }\end{array}$ & $\begin{array}{l}\text { c. } 20,000 \text { yrs cycles } \\
\text { potentially } \\
\text { resolvable. }\end{array}$ & $\begin{array}{l}\text { No - requires } \\
\text { calibration against } \\
\text { biochronological and } \\
\text { radiometric time } \\
\text { scales. }\end{array}$ & Basin limited & $\begin{array}{l}\text { Cyclostratigraphy is a } \\
\text { callibration tool rather } \\
\text { than correlative (cf. } \\
\text { Weedon et al. 1999) }\end{array}$ \\
\hline Volcanic 'events' & $\begin{array}{l}\text { A few weeks for ash to } \\
\text { settle. }\end{array}$ & $\begin{array}{l}\text { Depends on } \\
\text { duration of eruption, } \\
\text { but large eruption } \\
\text { typically last only a } \\
\text { few weeks although } \\
\text { large igneous } \\
\text { provinces may be } \\
\text { active for several } \\
\text { My. }\end{array}$ & $\begin{array}{l}\text { Yes - potential for } \\
\text { radiometric dating }\end{array}$ & $\begin{array}{l}\text { Continental scale } \\
\text { (c.3000 miles plus } \\
\text { for 'supervolcanoes'; } \\
\text { Self 2006) but more } \\
\text { likely to be } \\
\text { detectable regionally } \\
\text { or locally for most } \\
\text { typical eruptions. }\end{array}$ & $\begin{array}{l}\text { In Jurassic two major } \\
\text { provinces developed } \\
\text { (Central Atlantic } \\
\text { Magmatic Province) } \\
\text { and Karoo-Ferrar } \\
\text { (Ogg and Hinnox } \\
\text { 2012). Most other } \\
\text { volcanic activity only } \\
\text { regionally valuable for } \\
\text { correlations. }\end{array}$ \\
\hline $\begin{array}{l}\text { Large extra-terrestrial } \\
\text { Impact events }\end{array}$ & $\begin{array}{l}\text { A few weeks for ejecta } \\
\text { to settle. }\end{array}$ & $\begin{array}{l}\text { A few weeks for } \\
\text { materials to settle. }\end{array}$ & $\begin{array}{l}\text { Yes - although } \\
\text { limited potential for } \\
\text { radiometric dating, } \\
\text { infrequency can } \\
\text { make event } \\
\text { distinguishable in } \\
\text { sedimentary record }\end{array}$ & $\begin{array}{l}\text { Potentially global, } \\
\text { depending on size of } \\
\text { impact. }\end{array}$ & $\begin{array}{l}\text { At least } 3 \text { possible } \\
\text { events recorded (Ogg } \\
\text { and Hinnox 2012a)- } \\
\text { no significant } \\
\text { correlation potential } \\
\text { yet proven in the } \\
\text { Jurassic. }\end{array}$ \\
\hline
\end{tabular}

Figure 3 - Comparative resolution of the range of key tools used to correlate Jurassic rocks. 
An interesting point to note, however, is just how many other correlation schemes using fossils throughout other parts of the stratigraphical column are, or could be, defined in a similar way? For instance, should 'standard' graptolite zones in the Silurian (e.g. as used by Melchin et al. 2012) or 'standard' conodont zones in the Devonian (see Becker et al. 2012), actually be considered to be chronozones as well? After all, many have defined reference sections and have been used to define and correlate stage-level subdivisions - and they also fill their respective system's time scale without gaps or overlaps...

\section{Horizons}

A horizon, sensu gallico, is a sub-subchronozone and, therefore, should be treated as simply the finest subdivision of a standard chronostratigarphical hierarchy. As noted previously, the term zonule in the sense of Phelps (1985) and Page (1995, 2003) is synonymous, but as originally defined has a meaning closer to biostratigraphy (see below). Crucially, as with all other divisions in this hierarchy, horizons completely fill the stratigraphical column with no gaps or overlaps (and this is very evident from the way such units are tabulated, for instance in Cariou and Hantzpergue 1997). The use of horizons - and biohorizons - to facilitate higher resolution correlations at a regional scale helps ensure nomenclatural stability (and reduce confusion!) at a level of subchronozone and chronozone.

Although most horizons have been established on the basis of the presence of a specific ammonite assemblage and/or index species (which may or may not always be present), correlation does not depend on those assemblages being present, and hence beds above the recorded assemblage can still be included within the horizon, up to the level with the characteristic assemblage of the next, successive horizon.

\section{Biohorizons}

A biohorizon, however, is the smallest consecutive division which can be recognised on the basis of a single index species or assemblage within a maximum 
development of a stratigraphic interval (Page 1995). Biohorizons are synonymous with 'faunal horizons' sensu Callomon (1985a,b) and are effectively defined at both their base and top, i.e. the base of the biohorizon corresponds to the first occurrence of the correlating fauna and the top to its last occurrence. As such a biohorizon could be considered to be a 'hybrid' between biostratigraphy and chronostratigraphy, but it is conceptually considered to represent a 'faunal event', the expression of which may locally be modified by such factors as environmental controls of ecological significance or preservation, including diagenetic factors. Crucially, the same argument of practical isochroneity applies to the base of a biohorizon, just as it does for the base of an ammonite-correlated chronozone - it is just that the top of the former unit is defined as well. As such, a biohorizon can be considered to be a chronostratigraphical unit, the time 'content' of which is equivalent to a 'hemera' sensu Buckman (1893, etc) (following Callomon 1985a,b).

In addition, and part of the 'power' of using biohorizons, is that the 'gaps' between each defined unit can allow the correlation scheme to evolve as new information on the faunal sequence is revealed by later studies. This information can be 'inserted' into the existing scheme without disrupting its overall structure, including crucially at a subchronozone/ chronozone level. In this context, as well as using a diagnostic index species to identify each biohorizon, a consecutive numbering system can be used to identify successive units (e.g. Bj-1, Bj-2, etc for the Bajocian in Callomon and Chandler 1990 and Sn1 - Sn77 for the Sinemurian, see Figure 2) and helps avoid the need to remember long lists of ammonite species names.

As indicated previously, these explicit gaps or 'intervals' between each successful unit are where the 'changes' that allow each successive biohorizon to be recognised have taken place. But what are these observed ammonite 'events' and what is controlling them and facilitating their observation in the geological record? An attempt at answering this question considered the Upper Sinemurian biohorizonal sequence of Page (1992, as consolidated by Dommergues et al. 1994) and recognised five main controlling factors (Page 1995; see Figure 4 here but renumbered following Page 2009, 2010a,b):

1. Stages in the evolution of index genera, as recorded by periodic preservation (literally the "frames in a moving picture" of Bather 1927), e.g. Echioceras 


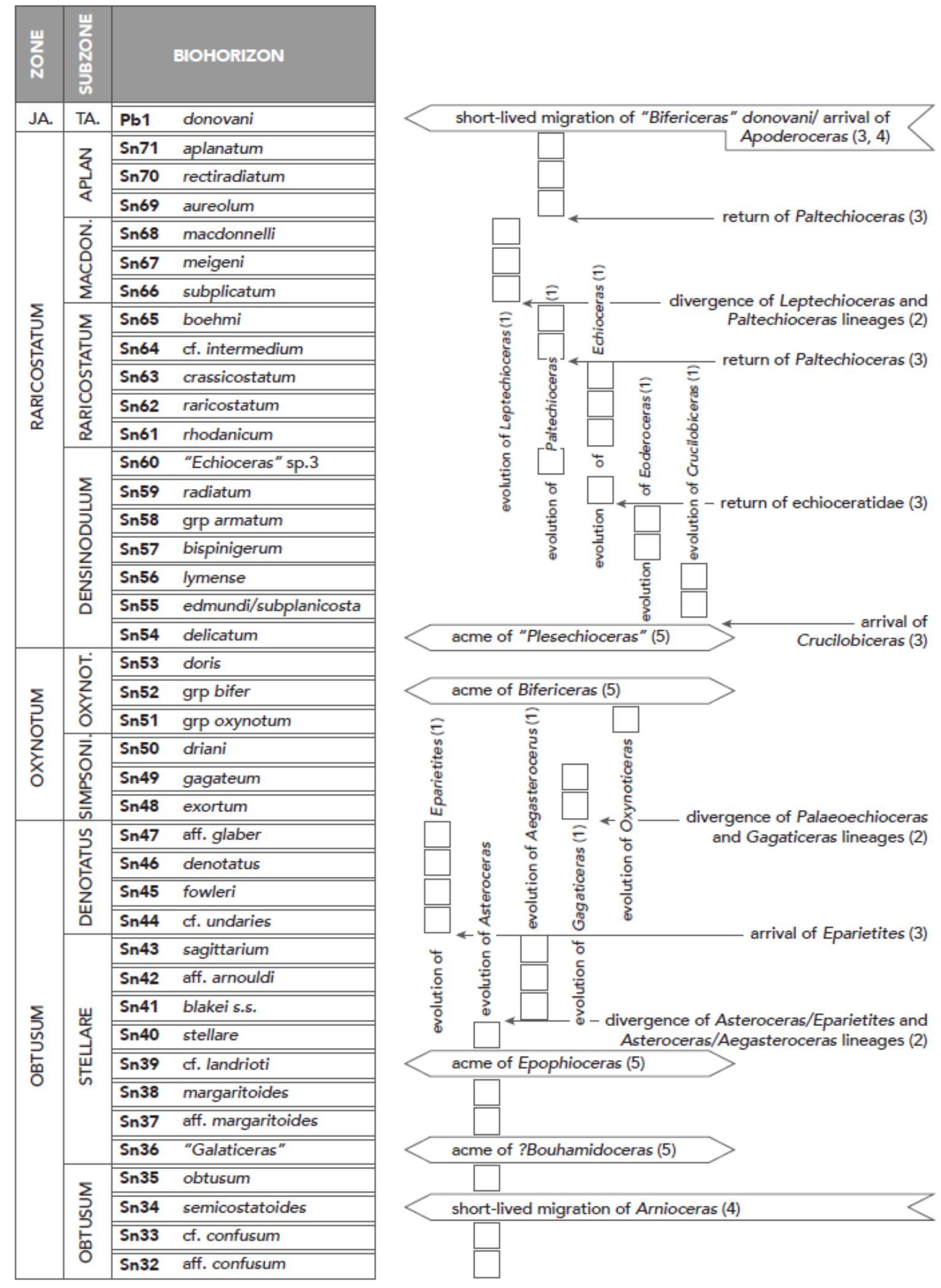

Figure 4 - Palaeobiological 'events' underlying the recognition of Lower Sinemurian biohorizons in the UK, potentially linked to periodic preservational control (for instance sequence stratigraphic or Milankovitch cycles; see text for discussion). 
rhodanicum S.S. Buckamn $\rightarrow$ E. raricostatum (Zieten) $\rightarrow$ E. crassicostatum (Trueman and Williams) (Sn61 to Sn63).

2. Speciation 'events' where an evolving lineage (i.e. genera) 'splits' into two or more genera/ subgenera, e.g. divergence of Asteroceras/ Eparietites and Asteroceras/Aegasteroceras lineages from Sn41.

3. 'Arrival' of new genera/ lineages (e.g. after origination in a separate biogeographical region), e.g. arrival of Eparietites in Sn44 followed by residence and continued evolution (e.g. in the context of 1. above) to Sn47 (= XVI in 1995) and beyond (as Oxynoticeras ex grp simpsoni (Simpson), etc.

4. Short-lived migration/residence of genus/species from a different biogeographical region, followed by disappearance, e.g. Arnioceras semicostatoides (Young and Bird) in Sn34.

5. Short-lived dominance or relative abundance of a genera/species (i.e. its 'acme' sensu Buckman), e.g. 'Bouhamidoceras / 'Galaticeras' in Sn36.

Factors 1, 2 and 5 are underwritten by basic ecological and evolutionary processes, although 3 and 4 may be controlled by much bigger, non-biological processes such as sea-level changes opening up and closing migration pathways (including through effects on oceanic currents). However, as an ammonite-correlated biohorizon can only be recognised when ammonites are preserved, there must also be sedimentological factors at work. Indeed, the very common and apparently 'periodic' preservation of ammonite assemblages in many areas (i.e. it is very unusual for ammonites to be uniformly abundant through any great thickness of sediment), must have some controlling factors. Obviously, there must be an interplay between ecological, sedimentological (including rates of sedimentation) and diagenetic factors, but what seems increasingly apparent is that processes way beyond pure biology are crucial for the 'expression' of a sequence of recognisable ammonite biohorizons. 
For example, in a sequence stratigraphic context, during a low stand, preservation of sediment containing an index fauna would be more likely in deeper, more offshore areas with more continuous sedimentation than in shallower areas where intermittent gaps (i.e. non-sequences) could be present. In addition, such scenarios can also help explain the characteristic cyclical changes in ammonite abundance that help characterise a sequence of biohorizons as the slowing down of sedimentation rates during high-stands and transgressions could periodically concentrate ammonite specimens in deeper water areas and hence facilitate characterisation of the morphological variation of assemblages with correlation potential (assuming a more or less constant rate of dead ammonite 'rain' onto the sea floor). The comparative sparsity of specimens in intervening levels and the resultant problems in characterising the variability of those few records obtained, would then be represented by the 'gap' between the defined biohorizons in the established biohorizonal scheme.

Additional factors will also be at work, and potentially the effects of extra-terrestriallydriven climate cycles may well be an important factor. It has long been established that such Milankovitch cycles can create a very strong impression in the sedimentary record as the cycles of climate change that they generate are recorded in the rocks as changes in rock type reflecting cyclical changes in environmental conditions. Such cycles are particularly obviously in mudrock-dominated sequences with a significant planktogenic carbonate input such as the famous 'Blue Lias' mudrocklimestone alternations in the Hettangian to Lower Sinemurian of SW England (Weedon 1986; Weedon et al., in press). These cyclical changes in ecological and diagenetic conditions could have had strong controls on ammonite presence and also, crucially, preservation (cf. Weedon et al. in press).

These changes would have been most strongly experienced amongst the shallower shelf seas of north-west Europe, with their scattering of further restricting islands, rather than in the deeper areas of the margins of the Tethys Ocean to the south-east (hence it is perhaps unsurprising that most of the currently recognised biohorizonal schemes have been established in the former region...). Nevertheless, many Tethyan sequences (e.g. pelagic limestones including ammonitico rosso facies) are also not uniformly rich in ammonite specimens, so there is no fundamental reason why biohorizonal schemes could not be established in such regions as well, 
providing that any potential reworking and mixing of assemblages of different ages can be appropriately assessed (for instance using the methodology of FernandezLopez 1991, 2000).

Returning to the actual duration of the observed biohorizon with its preserved fauna (as opposed to the average duration of a biohorizon-plus-interval as discussed previously), this will depend very much on this interplay between biological and sedimentological processes and even Buckman (including as reported by Arkell 1933) was under no misconception that this could vary from perhaps hundreds to many thousands of years, or more. In addition, it is quite likely that at different localities, the actual duration of the 'preservational event' recording the characteristic ammonite fauna might vary, for instance due to local sedimentological factors. Nevertheless, this variation is likely to be virtually impossible to quantify and is certainly well below anything which is likely to be resolvable through any other dating of correlative technique.

Since 1995, however, only a relatively few additional radiometric dates have been added to more meaningfully constrain Jurassic time (although, as also indicated previously, there may still be large errors due to the current lack of closely spaced, geochronologically dated levels), but there may be other ways to more accurate calibrate Jurassic time. As indicated previously, work in progress suggests that the average duration of the biohorizon-interval couplet in the Hettangian is likely to be somewhere between 36,000 and 60,000 years, but integration with cyclostratigraphical analysis offers the potential to estimate something much closer to the actual duration of each separate couplet, which are certainly highly unlikely to be all of a similar duration. In addition, a potential for direct U-Pb dating of wellpreserved aragonite from ammonite shells (cf. Li et al. 2015) provides an exciting potential for even more directly linking chronostratigraphical and geochronological time scales - but this is something for the future..

The 'proof of the [ammonite] pudding', however, is that biohorizonal schemes actually work for correlation purposes, suggesting that whatever are the controlling factors, many individual biohorizons could have a very wide geographical application. In the UK Sinemurian, for instance, the scheme of Page (1992) can be applied from north-west Scotland to south-west England - and after further 
collaborative investigation and tweaking was also found to work very well across France to Switzerland as well (Dommergues et al 1994) - effectively across the entire North West European ammonite Bioprovince (sensu Page 2008). Inevitably, however, some of the finest (bio-)stratigraphical detail might only be recognisable within parts of basins where more continuous sedimentation has provided a more complete record. Crucially, however, some of the more widely recognisable biohorizons can have a great potential for use as markers for the base of ammonite chronozones and subchronozones, hence ensuring a much wider applicability of a zonal scheme than might currently be available.

Two examples of the latter are the arrival of Neophyllites and hence the base of the Hettangian Hn3 biohorizon which was taken by Page (2010a) to mark the base of the second chronozone (i.e. Planorbis) of the Hettangian (and hence the Jurassic), thereby facilitating the correlation of the chronozone across the entire northern margin of Tethys, from the north of Ireland to Scotland, England, Germany, Austria and ultimately the Himalayas (including based on records of Bloos 1999, Bloos and Page 2000, Hillebrandt and Kment 2009, Yin et al. 2007). Secondly, the short lived migration of the Tethyan ammonite, Vermiceras grp. scylla (Reynès) across Europe was taken by Page (2003) to mark the base of the Lower Sinemurian, Bucklandi Subchronozone, facilitating its correlation from, at least, SW England (Page 1992), across eastern France (based on records in Guérin-Franiatte 1966) to the French Alps (Corna et al. 1997 - as Vermiceras kiliani Corna, Dommergues, Meister and Page ) and beyond to Italy (as recorded by Fucini 1902).

In these two cases, the underlying process behind the observed palaeobiological 'events' must be the palaeoeceanographic control of migration pathways. But what seems more generally evident, however, is that the observed sequence - or record of ammonite biohorizons across different sedimentary basins has as much to do with basin evolution, sequence stratigraphy and Milankovitch cyclicity, as it does with biological evolution. It is perhaps not surprising, therefore, that ammonites make such good correlation tools! 


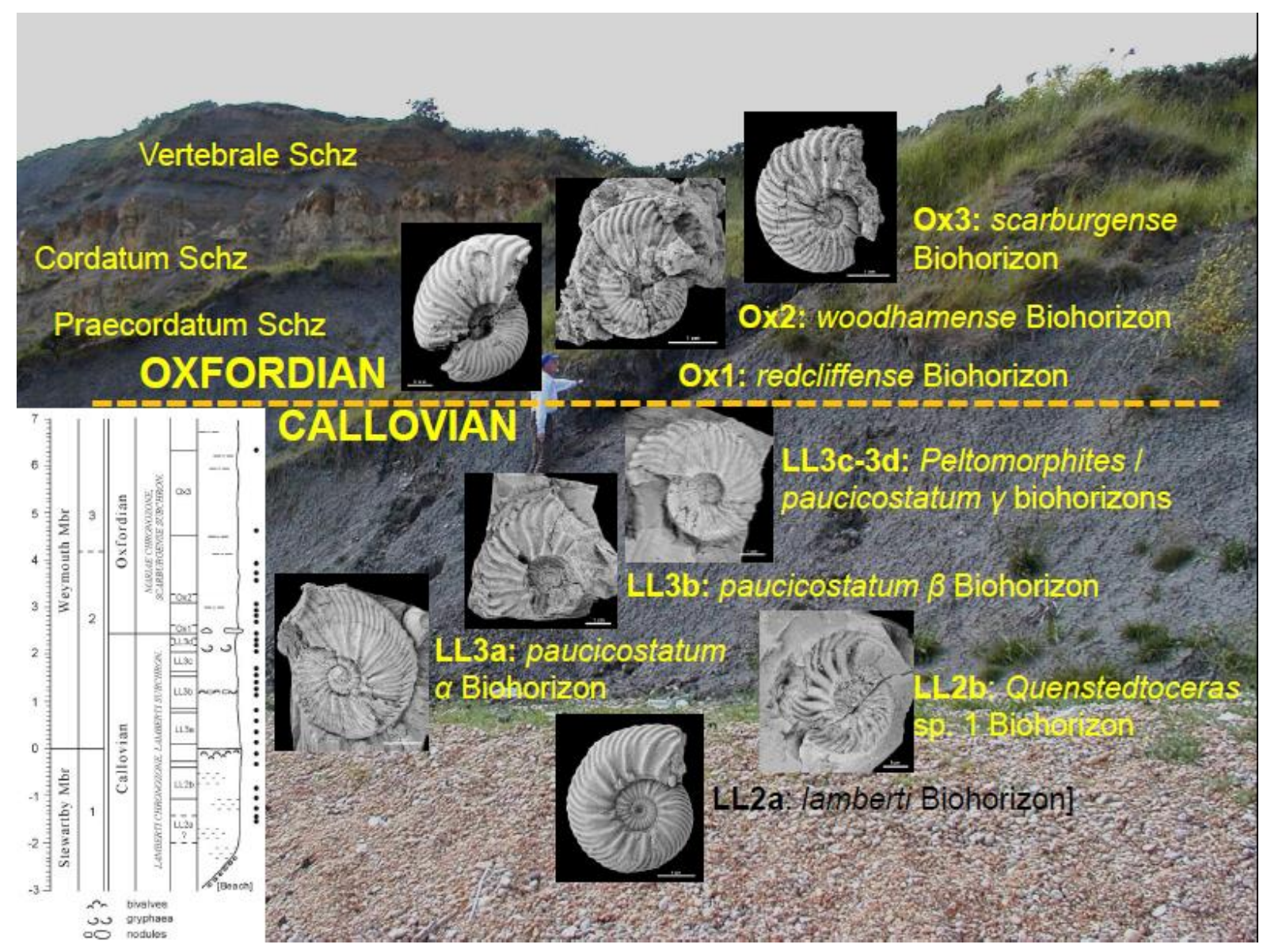

Figure 5 - Ammonite biohorizons in use - the provisional scheme for the Callovian-Oxfordian boundary at the Redcliff Point candidate GSSP, Weymouth, Dorset, SW England (including the selected index fossil for the base of the Oxfordian Stage,Cardioceras (Pavloviceras) redcliffense Page, Meléndez and Wright (2010). Biohorizons LL2a to LL3d are distinguished by species of Quenstedtoceras and Ox 1 to Ox3 by its direct descendent, Cardioceras - an excellent example of Bather's "frames in a moving picture". Section taken from Page et al. 2010 (Schz = Subchronozone). J.K. Wright provides a scale whilst indicating the proposed boundary level.

\section{Standardising stratigraphical nomenclature, GSSPs and the future!}

D’Orbigny and Oppel had both tried to establish an internationally applicable framework for correlating Jurassic rocks when they first established their stages, but it was not really until the publication of Arkell's 1956 study that the global potential of this framework was really demonstrated. However, debates, often across national borders, of precisely how the actual boundaries between these stages should be recognised continued and it was not until the late 1960s that the concept of defining 'boundary stratotypes' was first applied in an attempt to stabilise the meaning of the globally recognised stages which had been long established within the Jurassic.

The proposal was presented by a British group at the 1967 Jurassic Symposium in Luxembourg (Morton 1971) and not surprisingly most of all the proposed definitions 
for Jurassic stages were based on UK - specifically English - sequences. The term 'Global Stratotype Section and Point' (i.e. GSSP) is not yet used and the same volume confusingly publishes both a gallic and an anglo-celtic perspective on Jurassic stratigraphic nomenclature (Gabilly 1974 and Callomon and Donovan 1974) - but a desire to standardise and stabilise nomenclature is clear from both. Although an International Commission of Stratigraphical terminology had been first established in 1952 (Hedburg 1954) at what was then already the $19^{\text {th }}$ International Geological Congress (IGC), followed by the founding of the International Union of Geological Sciences in 1960, it was not until 1976 that an agreed International Stratigraphic Guide was eventually published (Hedberg 1976) and comprehensive guidelines for formally establishing GSSPs were not available until 1986 (Cowie et al. 1986, now superseded by Remane et al. 1996 and Gradstein et al. 2004).

Although the first ever GSSP was formally 'golden spiked' in 1972 to define the base of the Devonian System - at the very appropriate named 'Klonk' in the Czech Republic (Becker et al., 2012) - it was not until 1996 that the first GSSP for a Jurassic Stage was ratified for the Bajocian at Cabo Mondego in Portugal (Henriques et al. 1994; Pavia and Enay 1994). This was followed by the Sinemurian (Quantoxhead, Somerset, England; Bloos and Page 2002) and the Aalenian (Fuentelsaz, Guadalajara, Spain; Cresta et al 2001 ) in 2000, with the Pliensbachian in 2005 (Robin Hood's Bay, North Yorkshire, England; Meister et al. 2006), the Bathonian in 2008 (Bas-Auran, Haute-Provence, France; Fernández-López et al. 2009), the Hettangian in 2007 (i.e. basal Jurassic; Kuhjoch, Northern Calcareous Alps, Austria; Hillebrandt et al. 2007) and the Toarcian in 2010 (Peniche, Portugal; Rocha et al. 2016). In addition, formally designation of the GSSP for the base of the Kimmeridgian Stage is close (at Flodigarry, Isle of Skye, Scotland; Wierzbowski et al. 2015) and work on the two candidate Oxfordian stratotypes (e.g. Redcliff Point, Weymouth, England; Page et al. 2010 - see Figure 5 - or Thoux, Diois area, France; Pellenard et al. 2010) is nearing completion. Only the Callovian, Tithonian and the top of the system (i.e. the base of the overlying Berriasian Stage of the Cretaceous System) are outstanding, but progress is being made.

But are the ordered dreams of d'Orbigny and Oppel and their successors and disciples really this close to being realised?? The answer has to be 'not quite..'. Although only three boundaries remain to be formally established as GSSPs for the 
Jurassic, there are still no formal agreements on what really are the 'Standard' [ammonite] zonations' for each studied bioprovincial realm or province, i.e. the chronozones that are the correlative building blocks of the System. And even within existing zonations, many do not yet have an appropriate sequence of described horizons or biohorizons - and many non-ammonite workers continue to virtually ignore the possibilities of these highly refined chronologies even where they do exist. What is perhaps more worrying, however, is the all too common confusion - even commonly forced on authors by editors - about the true nature of ammonite zones. As John Callomon continuously reminded congresses, they are chronozones not biozones, they have been implicitly chronozones since Oppel's day, and as the stratigraphical building blocks of all 'modern' Jurassic stages, they must still be!

\section{Acknowledgements}

I would like to thank Marco Balini and Annalisa Ferretti for the initial invitation to take part in the session celebrating the anniversary of Albert Oppel at Strati 2015 in Graz, Austria, and support in the process of bringing this text to publication. I am grateful to Stephen Hesselbo, Chair of the ISJS, for supporting my attendance at the meeting. Graeme Taylor, Paul Cole, Arjan Dijkstra and Malcolm Hart (all Plymouth University), John McArthur (University College London) and Graham Weedon (Metrological Office) have all helped with valuable observations on the potential resolution of other correlative tools. An anonymous referee is thanked for a comprehensive review of the original text. Finally, I would like to acknowledge the many 'robust' discussions on stratigraphical practice and ammonitology I used to have with the late John Callomon, which kept me on the stratigraphical straight and narrow..

\section{References}

Arkell, W.J. 1933. The Jurassic System in Great Britain. Clarendon Press, Oxford. Arkell, W.J. 1935-1948. Monograph on the ammonites of the Corallian Beds. Monographs of the Palaeontographical Association. 
Arkell, W.J. 1936. The Corallian Beds of Dorset, Part 1: The coast. Proceedings of the Dorset Natural History and Archaeological Society 57, p.59.

Arkell, W. J. 1941. Map of the Corallian Beds around Highworth, Wiltshire. Wiltshire Natural History and Archaeological magazine, 59, p.274.

Arkell, W.J. 1956. Jurassic geology of the world. Oliver and Boyd Ltd, Edinburgh and London, 806pp.

Bather, F. A. 1927. Biological classification past and future. Quarterly Journal of the Geological Society of London, 83, Ixii-civ.

Balini, M., Annalisa Ferretti, A., Finney, S. and Monechi, S. (in press). The contribution of fossils to Chronostratigraphy, 150 years after Albert Oppel. Lethaia (this volume).

Becker, R. T., Gradstein, F. M. And Hammer, O. 2012. The Devonian Period. In: Gradstein, F. M., Ogg, J.G., Schmitz, M. and Ogg, G.. The Geologic Time Scale 2012, Elsevier, pp.731-791.

Birkelund, T., Callomon, J. H. \& Fürsich, F. T. 1984. The stratigraphy of the Upper Jurassic and Lower Cretaceous sediments of Milne Land, central East Greenland. Bulletin Gronlands Geologiske Undersogelse, 147 , 1-56.

Blau, J. and Meister, C. 2000. Upper Sinemurian Ammonite Sucessions based on 41 faunal horizons: an attempt at Worldwide correlation. In: Hall, R. L. and Smith, P. L. (eds.), Advances in Jurassic Research 2000. Proceedings of the Fifth International Symposium on the Jurassic System, GeoResearch Forum 6, Trans Tech Publications: 3-12.

Bloos, G. 1999. Neophyllites (Ammonoidea, Psiloceratidae) in the earliest Jurassic of south Germany. Neues Jahrbuch für Geologie und Paläontologie, Abhandlungen 211, 7-29.

Bloos, G. and Page, K. N. 2000. The basal Jurassic ammonite succession in the North-West European Province - Review and new results. In: Hall, R. L. and Smith, P. L. (eds.), Advances in Jurassic Research 2000. Proceedings of the Fifth 
International Symposium on the Jurassic System, GeoResearch Forum 6, Trans Tech Publications: 27-40.

Bloos, G. and Page, K.N. 2002. Global Stratotype Section and Point for base of the Sinemurian Stage (Lower Jurassic). Episodes 25 (1): 22-28.

Brongniart, A. 1829. Tableau des Terrains qui Composent L'écorce du Globe ou Essai sur la structure de la Partie Connue de la Terre. F. G. Levrault, Paris, 435pp.

Büch, L. von 1839. Uber den Jura in Deutschland. Physikalische Abhandlungen der koniglichen Akademie der Wissenschafien zu Berlin, Jahrgang 1837, 49-135.

Buckman, S. S. 1881. A descriptive catalogue of some species of ammonites from the Inferior Oolite of Dorset. Quarterly Journal of the Geological Society of London, 37, 588-608.

Buckman, S. S. 1887-1907. A monograph of the 'Inferior Oolite Series'. Monographs of the Palaeontographical Society, London., 456pp, PI. 1-CCLXII.

Buckman, S. S. 1893. The Bajocian of the Sherborne district: its relation to subjacent and superjacent strata. Quarterly Journal of the Geological Society of London, 49, 479-522.

Buckman, S. S. 1898. On the grouping of some divisions of so-called ,Jurassic'time. Quarterly Journal of the Geological Society of London 54: 442-462.

Buckman, S. S. 1902-1903. The term Hemera. Geological Magazine 9: 554-7; 10:956.

Buckman, S.S. 1909-1930: Yorkshire type ammonites $(\mathbf{1}, \mathbf{2})$ and Type ammonites (3-7), 790 plates. London \& Thame: Wheldon \& Wesley (1), the author (2-7).

Buckman, S. S. 1922. Jurassic chronology: 2- Preliminary Studies. Certain Jurassic strata near Eypesmouth (Dorset): the Junction Bed of Watton Cliff and associated rocks. Quarterly Journal of the Geological Society of London 78: 387-436.

Brinkmann, R. 1929. Statistisch-biostratigraphische Untersuchungen anmitteljurassischen Ammoniten tiber Artbegriff und Stammesentwicklung. Abhandlungen 
der Gesellschaft der Wissenschaften zu Gottingen,mathematische-physikalische Klasse, Neue Folge, 13, 3. Teil, 1-124.

Callomon, J. H. 1963. Sexual dimorphism in Jurassic ammonites. Transactions of the Leicester Literary and Philopsophical Society 57, 21-56.

Callomon, J. H. 1965. Notes on Jurassic stratigraphical nomenclature. I. Principles of stratigraphical nomenclature. Reports, VII Congress of the Carpatho-Balkan Geological Association, Sofia, part ii, vol. 1, 81-85.

Callomon, J. H. 1984. The measurement of geological time. Proceedings of the Royal Institution of London, 56, 65-99.

Callomon, J. H. 1985a. A review of the biostratigraphy Callomon, J.H. 1984:

Biostratigraphy, chronostratigraphy and all that - again! In: Michelsen, O. and Zeiss, A. (eds): International Symposium on Jurassic stratigraphy (Erlangen 1984) 3, 611624. Copenhagen: Geological Survey of Denmark.

Callomon, J.H. 1985b. The evolution of the Jurassic ammonite family Cardioceratidae. Special Papers in Palaeontology 33: 49-90.

Callomon, J.H. 1993. The ammonite succession in the Middle Jurassic of East Greenland. Bulletin of the Geological Society of Denmark, 40, 83-113.

Callomon, J.H. 1995. Time from fossils: S.S. Buckman and Jurassic high-resolution geochronology. In: Le Bas, M.J. (ed.). Milestones in Geology. Geological Society Memoir, 16: 127-150.

Callomon, J.H. and Birkelund, T. 1980. The Jurassic transgression and the mid-late Jurassic succession in Milne Land, central East Greenland. Geological Magazine, 117, 211-226.

Callomon, J.H. and Birkelund, T. 1982. The ammonite Zones of the Boreal Volgian (Upper Jurassic) in East Greenland. In: EMBRY, A. F. and Balkwill, H. R. (eds) Arctic Geology and Geophysics. Canadian Society of Petroleum Geologists, Memoirs, 8 , 349-369. 
Callomon, J.H. and Chandler, R. B. 1990. A review of the ammonite horizons of the Aalenian-Lower Bajocian Stages in the Middle Jurassic of southern England. Memorie descrittive della Carta geologica d'Italia, 40, 85-111.

Callomon, J.H., Dietl, G. and Niederhöfer, H. J. 1989: Die AmmonitenfaunenHorizonte im Grenzbereich Bathonium/Callovium des Schwäbischen Juras und deren Korrelation mit Westfrankreich und England. Stuttgarter Beiträge zur Naturkunde, (B), 148: 1-13.

Callomon, J.H. , Dietl, G. and Page, K. N. 1989. On the ammonite faunal horizons and standard zonations of the Lower Callovian Stage in Europe. In: Rocha, R. B. \& Zeiss, A. (eds) 2nd International Symposium on Jurassic Stratigraphy, Lisboa 1987, 1. Universidade Nova, Lisbon, 359-376.

Callomon, J. H. and Donovan, D.T. 1971. A code of Mesozoic Stratigraphical Nomenclature. In: Colloque du Jurassique, Luxembourg, 1967. Mémoires du Bureau de Récherches Géologiques et Minières, Paris, 75, 75-81.

Cariou, E., Elmi, S., Mangold, C., Thierry, J. and Tintant, H. 1974. La sucession des faunes dans le Callovien Francais: Essai de Correlation a l'echelle de la zone. In: Colloque du Jurassique, Luxembourg, 1967. Mémoires du Bureau de Récherches Géologiques et Minières, Paris, 75, 665-692.

Cariou, E. and Hantzpergue, P. (eds) 1997: Biostratigraphie du Jurassique ouesteuropéen et méditerranéen. Bulletin du Centre Recherches Elf Exploration et Production Mémoire 17.

Clémence, M.-E., Bartolini, A., Gardin, S., Paris, G., Beaumont, V. and Page, K.N. 2010. Early Hettangian benthic-planktonic coupling at Doniford (SW England): Palaeoenvironmental implications for the aftermath of the end Triassic crisis. Palaeogeography, Palaeoclimatology, Palaeoecology 295: 102-115.

Cope, J. C. W. 1967. The palaeontology and stratigraphy of the lower part of the Upper Kimmeridge Clay. Bulletin of the British Museum (Natural History), geology 15 (1).

Cope, J. C. W. 1978. The ammonite faunas and stratigraphy of the upper part of the Upper Kimmeridge Clay of Dorset. Palaeontology 21, 469-533. 
Corna, M., Dommergues, J.-L., Meister, C. and Page, K.N. 1997. Les ammonites du Jurassique inférieur (Hettangien, Sinémurian et Pliensbachian) au nord du massif des Écrins (Oisans, Alpes occidentales françaises). Revue Paléobiologie, Genève 16:

Cowie, J. W., Ziegler, W., Boucot, A. J., Bassett, M. G. and Remane, J. 1986. Guidelines and statutes of the International Commission on Stratigraphy. Courier des Forschungsinstitut Senckenberg, 83, 1-14.

Cox, B.M. 1990. A review of Jurassic chronostratigraphy and age indicators for the UK. In: Hardman, R.F.P. and Brooks, J. (eds): Tectonic events responsible for Britain's oil and gas reserves. Geological Society Special Publication (London) 55, 169-190.

Cresta S., Goy A., Ureta S., Arias C., Barrón E., Bernad J., Canales M. L., García Joral F., García-Romero E., Gialanella P. R., Gómez J. J., González J. A., Herrero C., Martínez G., Osete M.L., Perilla N. and Villalaín J. J. 2001. The Global Boundary Stratotype Section and Point (GSSP) of the Toarcian-Aalenian Boundary (LowerMiddle Jurassic), Episodes, 24, 3: 166-175.

Dean, W.T., Donovan, D.T. and Howarth, M.K. 1961: The Liassic ammonite zones and subzones of the north-west European Province. Bulletin of the British Museum (Natural History), Geology Series 4, 435-505.

Dietl, G. 1994: Der hochstetteri-Horizont - ein Ammonitenfaunen-Horizont (DiscusZone, Ober-Bathonium, Dogger) aus dem Schwäbischen Jura. - Stuttgarter Beiträge zur Naturkunde, (B), 202: 1-39.

Dietl, G. and Callomon, H. 1988: Der Orbis-Oolith (Ober-Bathonium, Mittl. Jura) von Sengenthal/Opf., Fränk. Alb, und seine Bedeutung für die Korrelation und Gliederung der Orbis-Zone. Stuttgarter Beiträge zu für Naturkunde, (B), 142: 1-31.

Dommergues, J.L., Page, K.N. and Meister, C. 1994. A detailed correlation of Upper Sinemurian (Lower Jurassic) ammonite biohorizons between Burgundy (France) and Britain. Newsletters in Stratigraphy 30: 61-73.Donovan 1952,

D’ Orbigny, A. 1842-1849. Paléontologie francaise; terrains jurassiques. Masson, Paris. 
Enay, R., Tintant, H. and Cariou, E. 1974. Les faunes Oxfordiennes d'Europe: essai de zonation. In: Colloque du Jurassique, Luxembourg, 1967. Mémoires du Bureau de Recherches Géologiques et Minières, Paris, 75, 635-664.

Fenton, C.L. \& Fenton, M.A. 1928. Ecologic interpretations of some biostratigraphic terms. American Midland Naturalist, 11, 1-23.

Fernández-López, S., 1991. Taphonomic concepts for a theoretical biochronology. Revista Española de Paleontología 6: 37-49.

Fernández-López, S., 2000. Ammonite taphocycles in carbonate epicontinental platforms. In: Hall, R. L. and Smith, P. L. (eds.), Advances in Jurassic Research 2000. Proceedings of the Fifth International Symposium on the Jurassic System, GeoResearch Forum 6, Trans Tech Publications: 293-300.

Fucini, A. 1902. Cefalopodo di liassici del Monte di Cetona. Palaontologica Italica, 8, p.131.

Gabilly, J. 1974. Methodes et modeles en stratigraphie du Jurassique. In: Colloque du Jurassique, Luxembourg, 1967. Mémoires du Bureau de Recherches Géologiques et Minières, Paris, 75, 5-16.

Gabilly, J., Elmi, S., Mattei, J., Mouterde, R. and Rioult, M. 1974. L'etage Toarcien: zones et sous-zones d'ammonites. In: Colloque du Jurassique, Luxembourg, 1967. Mémoires du Bureau de Recherches Géologiques et Minières, Paris 75, 605-634.

Gayrard-Valy, Y. 1994. The story of fossils : In search of vanished worlds. Thames and Hudson, 191pp. (original published in French by Gallimard in 1987).

Gradstein, F., Ogg, J. and Smith, A. 2004. In: Gradstein, F., Ogg, J. and Smith, A., A Geological Time Scale 2004. Cambridge University Press, pp.20-46.

Guérin-Franiatte, S. 1966. Ammonites du Lias inférieur de France, Psilocerataceae: Arietitidae, Éditions du Centre National de la Recherche Scientifique, Tome 1, 455 pp.

Harland, W. B., Armstrong, R. L., Cox, A. V., Craig, L. E., Smith, A. G. and Smith, D. G. 1990. A geological time scale 1989. Cambridge University Press, 263pp. 
Hedberg, H. D. 1954. Procedure and terminology in stratigraphical classification. Congres Geologique International. Comptes rendus de la XIX Session, Alger 1952. Section XIII, 1. partie: fasc.xiii, 205-233.

Hedberg, H. D. 1976. International Stratigraphic Guide. Wiley \& Sons, New York. Heinze, C., Meyer, S., Anderson, L., Steinfeldt, R., Chang, N., Le Ouéré, C. And Bakker, D. C. E. 2015. The ocean carbon sink - impacts, vulnerabilities and challenges. Earth System Dynamics 6 : 327-358.

Henriques, M. -H., Gardin, S., Gomes, C.R., Soares, A. F., Richa, R. B., Marques, J. F., Lapa, M. R., Montenegro, J. D. 1994. The Aalenian-Bajocian biundary at cabo Mondego (Portugal). In: Cresta, S., Pavia, G. (eds). Proceedings of the $3^{\text {rd }}$ International Meeting on Aalenian and Bajocian Stratigraphy. Miscellanea del Servizioo Geologico Nazionale, 5: 63-77.

Hillebrandt, A, Von, Krystyn, L. and Kuerschner, W.M. With contributions from Bown, P.R., Mcroberts, C., Ruhl, M., Simms, M., Tomasovych, A., Urlichs, M. 2007. A candidate GSSP for the base of the Jurassic in the Northern Calcareous Alps (Kuhjoch section, Karwendel Mountains, Tyrol, Austria. International Subcommission on Jurassic Stratigraphy, Newsletter 24/1: 2-20.

Hillebrandt, A. von and Kment, K. 2015. Psiloceratid ammonites from the Lower Hettangian of the Karwendel Mountains (Northern Calcareous Alps, Austria) and their biostratigraphical significance. Neues Jahrbuch für Geologie et Palaontologie. Abh. 277: 275-306.

Howarth, M. K. 1992. The ammonite family Hildoceratidae in the Lower Jurassic of Britain. Monograph of the Palaeontographical Society, London, 200pp, PI.1-38.

Humboldt, A. von 1799. Uber die Unterirdischen Gasarten unddie Mittel ihren Nachtheirl zu Verminden. Ein Beitrag zur Physik der Praktischen Bergbaukunde. Brainschweig, Wiewag, p.384.

Humboldt, A. von 1823. Essai géognostique sur le gisement des Roches, pp. 269, 275. 
Jenkyns H.C., Jones C.E., Grocke D.R., Hesselbo S.P. and Parkinson D.D. 2002. Chemostratigraphy of the Jurassic System: applications, limitations and implications for palaeoceanography. Journal of the Geological Society, London. 159: 351-378.

Kemp, D. B., Coe, A. L., Cohen, A. S., \& Weedon, G. P. 2011. Astronomical forcing and chronology of the early Toarcian (Early Jurassic) oceanic anoxic event in Yorkshire, UK. Paleoceanography, 26, PA4210, doi:10.1029/2011PA002122.

Kiselev D., Rogov M., Glinskikh, L., Guzhikov A., Pimenov M., Mikhailov, A., Dzyuba, O., Matveev, A. and Tesakova E.. 2006. Integrated stratigraphy of the reference sections for the Callovioan-Oxfordian boundary in European Russia. Volumina Jurassica, 11: 59-96.

Li, Q., Parrish, R. R., Horstwood, M. S. A. and McArthur, J. M. 2015. U-Pb dating of cements in Mesozoic ammonites. Chemical Geology 376 (2014) 76-83

Loydell, D. K. 1993. Worldwide correlation of Telychian (Upper Llandovery) strata using graptolites. In: Hailwood, E. A. and Kidd, R.B. (eds) High Resolution Stratigraphy. Geological Society, London, Special Publication, 70, 323-340.

Mangold, C., Elmi, S. and Gabilly, J. 1974. Les faunes du Bathonie dans le Moitie sud de la France: essai de zonation et de correlations. In: Colloque du Jurassique, Luxembourg, 1967. Mémoires du Bureau de Récherches Géologiques et Minières, Paris, 75, 103-132.

McArthur, J., Howarth, R. J. and Shields, G. A. 2012. Strontium Isotope Stratigraphy. In: Gradstein, F. M., Ogg, J.G., Schmitz, M. and Ogg, G.. The Geologic Time Scale 2012, 1: 127-144 Elsevier.

McArthur, J., Steuber, T., Page, K.N. and Landman, N. 2016. Sr-isotope stratigraphy scaling the Campanian, Pliensbachian, Toarcian, and Valanginian. Journal of Geology, 124: 569-586.

Melchin, M. J., Sadler, P. M. and Cramer, B. D. 2012. The Silurian Period. In: Gradstein, F. M., Ogg, J.G., Schmitz, M. and Ogg, G.. The Geologic Time Scale 2012, Elsevier, pp.525-528. 
Meister, C., Aberhan, M., Blau, J., Dommergues, J.-L., Feist-Burkhardt, S., Hailwood, E., Hart, M., Hesselbo, S.P., Hounslow, M.W., Hylton, M., Morton, N., Page, K. And Price, G.D. 2006. The Global Stratotype Section and Point (GSSP) for the base of the Pliensbachian Stage (Lower Jurassic), Wine haven, Yorkshire, UK. Episodes 29: 93-114.

Mokadem, Fatima; Parkinson, lan J.; Hathorne, Ed C.; Anand, Pallavi; Allen, John T. and Burton, Kevin W. (2015). High precision radiogenic strontium isotope measurements of the modern and glacial ocean : limits on glacial-interglacial variations in continental weathering. Earth and Planetary Science Letters, 415. 111120.

Mönnig, E. 2010. On the systematic of the ammonite genus Kepplerites and its occurrence in the Koenigi Zone (Callovian, Middle Jurassic of Central Europe and England. Earth Science Frontiers, special Issue 17: 117-119.

Mönnig, E. 2014.The stratigraphy of the Bathonian-Callovian boundary (Middle Jurassic) in Northern Germany. Neues Jahrbuch fur Geologie und Palaontologie, Abhandlungen. 274: 271-290.

Mönnig, E. (in press). The evolution of Oppel's 'Macrocephalusbett' (Callovian, Middle Jurassic). Lethaia (this volume)

Morton, N. 1971 (ed.). The definition of Standard Jurassic Stages. Colloque du Jurassique, France 1967. Mémoire Bureau de Recherche Geologique et Minière, France $75: 83-93$.

Mouterde, R. and Corna, M. 1997: Hettangien. In : Cariou, E. \& Hantzpergue, P. (eds) : Biostratigraphie du Jurassique ouest-européen et méditerranéen : zonations parallèles et distribution des invertébrés et microfossiles. Bulletin du Centre Recherches Elf Exploration et Production Mémoire 17, 7-8.

Ogg, J.G. and Hinnov, L.A. 2012a. Jurassic. In: Gradstein, F. M., Ogg, J.G., Schmitz, M. and Ogg, G.. The Geologic Time Scale 2012, 2 Elsevier, pp.731-791.

Ogg and Hinnov 2012b. Cretaceous. In: Gradstein, F. M., Ogg, J.G., Schmitz, M. and Ogg, G.. The Geologic Time Scale 2012, 2. Elsevier, pp.793-853. 
Oppel, A. 1856-1858. Die Juraformation Englands, Frankreichs und des Sudweslichen Deutschlands. Bner and Seubert, Stuttgart, pp.857.

Page, K.N. 1992. The sequence of ammonite correlated horizons in the British Sinemurian (Lower Jurassic). Newsletters in Stratigraphy 27, 129-15.

Page, K.N. 1995. Horizons; Intra-subzonal units in Jurassic ammonite stratigraphy. Palaeontology 38: 801-814.

Page, K.N. 2003. The Lower Jurassic of Europe - its subdivision and correlation. In: Surlyk, F., Dybkjaer, K., Ineson, J., Nielsen, L.H. and Poulsen, N.E. (eds). The Jurassic of Denmark and adjacent areas. Special volume of the Geological Survey of Denmark 1: 23-59.2004,

Page, K.N. 2004. A sequence of biohorizons for the Subboreal Province Lower Toarcian in Northern Britain and their correlation with a Submediterranean Standard. Rivista Italiana di Paleontologia e Stratigrafia 110: 109-114.

Page, K.N. 2005. The Hettangian ammonite faunas of the West Somerset coast (south west England) and their significance for the correlation of the candidate GSSP (Global Stratotype and Point) for the base of the Jurassic System at St. Audries Bay. In: Hanzo, M. (coord.), Colloque Hettangien à Hettange, de la science au patrimoine, Hettange, 1-3 avril 2005: 15-19. Unversité Henri Poncaré, Nancy.

Page, K.N. 2008. The evolution and geography of Jurassic ammonites. Proceedings of the Geologist's Association 119: 35-57.

Page, K.N. 2010a. High resolution ammonite stratigraphy of the Charmouth Mudstone Formation (Lower Jurassic: Sinemurian-Lower Pliensbachian) in southwest England (UK). Volumina Jurassica 7: 19-29.

Page, K.N. 2010b. Stratigraphical Framework. In: Lord, A.R. and Davis, P.G. Fossils from the Lower Lias of the Dorset Coast, Palaeontological Association Field Guide to Fossils 13: 33-53.

Page, K.N. and Mélendez, G. 2000. Correlation of Late Bathonian ammonite faunas between England and North East Spain and a proposed standard zonation for the Upper Bathonian of northern and eastern Europe. In: HALL, R. L. and SMITH, P. L. 
(eds.), Advances in Jurassic Research 2000. Proceedings of the Fifth International Symposium on the Jurassic System, GeoResearch Forum 6, Trans Tech Publications: 153-162.

Page, K.N., Meléndez, G. and Wright, J.K. 2010. The ammonite faunas of the Callovian- Oxfordian boundary interval in Europe and their relevance to the establishment of an Oxfordian GSSP. Volumina Jurassica 7: 89-99.

Page, K. N., Wright, J. K. and Kelly, S. R. A. 2015. The oppeliid, perisphinctid and aspidoceratid ammonite faunas of the 'Corallian' Beds (Upper Jurassic) in Cambridgeshire, England. Proceedings of the Yorkshire Geological Society ( DOI:10.1144/pygs2015-355).

Page, K.N., Meléndez, G., Hart, M.B., Price, G.D., Wright, J.K., Bown, P. and Bello, J. 2010. Integrated staitigraphical study of the candidate Oxfordian Global Stratotype Section and Point (GSSP) at Redcliff Point, Weymouth, Dorset, UK. Volumina Jurassica 7: 101-111.

Pavia G. and Enay R., 1997. Definition of the Aalenian-Bajocian Stage Boundary. Episodes, 20: 16-22.

Pellenard, P., Fortwengler, D., Marchand, D., Thierry, J., Bartolini, A., Boulila, S., Collin, P.Y., Enay, R., Galbrun, B., Gardin, s., Huault, V., Huret, E., Martinez, M., Chateau Smith, S. 2014. Integrated stratigraphy of the Oxfordian global stratotype section and point (GSSP) candidate in the Subalpine Basin (SE France). Volumina Jurassica 12: 1-44.

Phelps, M.C. 1985: A refined ammonite biostratigraphy for the Middle and Upper Carixian (Ibex and Davoei zones, Lower Jurassic) in north-west Europe and stratigraphical details of the Carixian-Domerian boundary. Geobios 18, 321-367.

Phillips, J. 1829. Illustrations of the Geology of Yorkshire: Part 1-The Yorkshire Coast. John Murray, London.

Phillips, J. 1871. Geology of Oxford and the valley of the Thames, Clarendon Press, Oxford.

Quenstedt, F. A. Von, 1856-1858, Der Jura. Tübingen. 
Quenstedt, F. A. Von, 1883-1888. Die Ammoniten des Schwabischen Jura 1-3, Stuttgart.

Raup, D. M. and Sepkoski, J.J., 1984. Periodicities of extinctions in the geologic past. Proceedings of the National Academy of Sciences, USA 81: 801-805.

Remane J., Bassett M. G., Cowie J. W., Gohrbandt K.H., Lane R. H., Michelsen O. and Naiwen W. 1996. Revised guidelines for the establishment of global chronostratigraphic standards by the International Commision on Stratigraphy (ICS). Episodes, 19: 77-81.

Rioult, M. 1971. Alcide d'Orbigny et les etages du Jurassique. In: Colloque du Jurassique, Luxembourg, 1967. Mémoires du Bureau de Recherches Géologiques et Minières, Paris, 75, 17-33.-16.

Rocha, R. B., da, Mattioli, E., Duarte, L. V., Pittet, B., Elmi, S., Mouterde, R., Cabral, M. -C., Comas-Rengifo, M. -J., 6, Gómez, J. -J., Goy, A., Hesselbo, S. P., Jenkyns, H. -C., Littler, K., Mailliot, S. , Veiga de Oliveira, L. C., Osete, M. -L., Perilli, N., Pinto, S., Ruget, S. and Suan, G. 2016. Base of the Toarcian Stage of the Lower Jurassic defined by the Global Boundary Stratotype Section and Point (GSSP) at the Peniche section (Portugal). Episodes, October 2016. DOI:

0.18814/epiiugs/2016/v39i3/99741

Ruhl, M., Deenen, M.H.L., Abels, H.A., Bonis, N.R., Krijgsman, and Kürschner, 2010. Astronomical constraints on the duration of the early Jurassic Hettangian stage and recovery rates following the end-Triassic mass extinction (St. Audries Bay/East Quantoxhead, UK). Earth and Planetary Science. Letters 296, pp262-276.

Schaltegger, U., Guex J., Bartolini, A., Schoene, B., Ovtcharova, M. 2007. Precise $\mathrm{U}-\mathrm{Pb}$ age constraints for end-Triassic mass extinction, its correlation to volcanism and Hettangian post-extinction recovery. Earth and Planetary Science Letters 267 (2008) 266-275

Schmitz, M. D. 2012. Radiometric Isotope Geochronology. In: Gradstein, F. M., Ogg, J.G., Schmitz, M. and Ogg, G.. The Geologic Time Scale 2012, 2. Elsevier, pp.115126. 
Self, S. 2006. The effects and consequences of very large explosive volcanic eruptions. Philosophical transactions of the Royal Society A 364: 2073-2097.

Smith, W. 1799. 'Table of the Order of Strata and their embedded Organic Remains in the vicinity of Bath, examined and proved prior to 1799'. Unpublished MS map and table presented to the Geological Society of London.

Smith, W. 1815. Geological map of England and Wales. London.

Smith, W. 1816--1819. Strata Identified by Organized Fossils. Parts 1-2, 1816; Part 3, 1817; Part 4, 1819. Aarding, London.

Townsend, J. 1813. Tables of strata. In: The Character of Moses established for veracity as an Historian, recording events form the creation to the deluge, pp.100 et seq.

Weedon, G.P., 1986. Hemipelagic shelf sedimentation and climatic cycles: the basal Jurassic (Blue Lias) of South Britain. Earth and Planetary Science Letters. 76, 321335.

Weedon, G. P., Jenkyns, H. C., Coe, A. L. and Hesselbo, S. P. 1999. Astronomical calibration of the Jurassic time-sacle from cyclostratigraphy in British mudrock formations. Philosophical Transactions of the Royal Society London A: 357: 17871813.

Weedon, G.P., Jenkyns, H.C. and Page, K. N.. (in press). A dynamic model for combined sea level and climate controls of limestone formation, hiatuses and ammonite preservation in the Blue Lias Formation of southern, South Britain (latest Triassic-Early Jurassic). Geological Magazine (accepted December 2016).

Whittaker, A., Cope, J. C. W., Cowie, J.W., Gibbons, W., Hailwood, E. A., House, M. R., Jenkins, W. D., Rawson, P. F., Rushton, A. W. A., Smith. D. G.. Thomas, A. T. and Wimbledon, W.A. 1991. A guide to stratigraphical procedure. Journal of the Geological Society, London 148: 813-824.

Winkelmann I., Campos P.F.,Strugnell, J, Cherel, Y., Smith, P.J., Kubodera, T., Allcock L., Kampmann, M.-L., Schroeder, H,, Guerra, A., Norman, M,, Finn, J., Ingrao, D,, Clarke, M. and Gilbert, M.T.P. 2013 Mitochondrial genome.diversity and 
population structure of the giant squid Architeuthis: genetics sheds new light on one of the most enigmatic marine species. Proceedings of the Royal Society $B$ 280: 20130273. http://dx.doi.org/10.1098/rspb.2013.0273

Woodward, H. 1893. The Jurassic rocks of Britain 3: The Lias of England and Wales (Yorkshire excepted). Memoirs of the Geological Survey of the United Kingdom, 399pp.

Wiezbowski, a. \& Matyja, B.A., 2014. Ammonite biostratigraphy in the Polish Jura sections (central Poland) as a clue for recognition of the uniform base of the Kimmeridgian Stage. Volumina Jurassica, 12: 45-98.

Wierzbowski, A., Atrops, F., Grabowski, J., Hounslow, M.W., Matyja, B.A., Olóriz, F., Page, K.N., Parent, H., Rogov, M.A., Schweigert, G., Villaseñor, A. -B, Wierzbowski, H. and Wright, J.K. 2015. Towards a consistent Oxfordian-Kimmeridgian global boundary: current state of knowledge. Volumina Jurassica 14: 14-49.

Yin, J., Paul L. Smith, P. L., Palfy, J. and Enay, R. 2007. Ammonoids and the TriassicJurassic boundary in the Himalayas of southern Tibet. Palaeontology, 50, 711-737. 